\title{
Impact of moderate energetic fine-scale dynamics on the phytoplankton community structure in the western Mediterranean Sea
}

Roxane Tzortzis ${ }^{1}$, Andrea M. Doglioli ${ }^{1}$, Stéphanie Barrillon ${ }^{1}$, Anne A. Petrenko ${ }^{1}$, Francesco d'Ovidio ${ }^{2}$, Lloyd Izard ${ }^{2}$, Melilotus Thyssen ${ }^{1}$, Ananda Pascual ${ }^{3}$, Bàrbara Barceló-Llull ${ }^{3}$, Frédéric Cyr ${ }^{4}$, Marc Tedetti ${ }^{1}$, Nagib Bhairy ${ }^{1}$, Pierre Garreau ${ }^{5}$, Franck Dumas ${ }^{6}$, and Gérald Gregori ${ }^{1}$

${ }^{1}$ Aix Marseille Univ., Université de Toulon, CNRS, IRD, MIO, Marseille, France

${ }^{2}$ Sorbonne Université, CNRS, IRD, MNHN, Laboratoire d'Océanographie et du Climat : Expérimentations et Approches Numériques (LOCEAN-IPSL), Paris, France

${ }^{3}$ IMEDEA (CSIC-UIB), Instituto Mediterráneo de Estudios Avanzados, Esporles, Spain

${ }^{4}$ Northwest Atlantic Fisheries Centre, Fisheries and Oceans Canada, St. John's, NL, Canada

${ }^{5}$ UMR 6523 CNRS, IFREMER, IRD, UBO, Laboratoire d'Océanographie Physique et Spatiale, Plouzané 29280, France

${ }^{6}$ SHOM, Service Hydrographique et Océanographique de la Marine, 13 rue de Chatellier, CS592803, 29228 Brest, CEDEX 2, France

Correspondence: Roxane TZORTZIS (roxane.tzortzis@ mio.osupytheas.fr)

\begin{abstract}
.
Model simulations and remote sensing observations show that ocean dynamics at fine scales (1-100 km in space, day-weeks in time) strongly influence the distribution of phytoplankton. However, only few in situ samplings have been performed and most of them in boundary currents which may not be representative of less energetic regions. The PROTEVSMED-SWOT cruise took place in the moderately energetic waters of the western Mediterranean Sea, in the southern region of the Balearic Islands. Taking advantage of near-real time satellite information, a sampling strategy was defined in order to cross a frontal zone separating different water masses. Multi-parametric in situ sensors mounted on the vessel, on a towed fish and on an ocean glider were used to sample at high spatial resolution both physical and biogeochemical variables. A particular attention was put in adapting the sampling route, in order to also estimate the vertical velocities in the frontal area. Such a strategy was successful in sampling quasi-synoptically an oceanic area characterized by the presence of a narrow front with an associated vertical circulation. A multiparametric statistical analysis of the collected data identifies two water masses characterized by different abundances of several phytoplankton cytometric functional groups, as well as different contents in chlorophyll $a$ and $\mathrm{O}_{2}$. Our study shows that the Lagrangian fronts induced by the fine-scale circulation, even if much weaker than the fronts occurring in boundary current systems, maintain a strong structuring effect on phytoplankton community by segregating different taxa at the surface.
\end{abstract}


https://doi.org/10.5194/bg-2021-38

Preprint. Discussion started: 2 March 2021

(c) Author(s) 2021. CC BY 4.0 License.

\section{(c) (i)}

\section{Introduction}

Phytoplankton diversity is essential for the functioning of the oceanic ecosystem (Ptacnik et al., 2008). As such, its role on biogeochemical cycles, including $\mathrm{CO}_{2}$ recycling (Watson et al., 1991) is an important compartment to study, particularly in the context of global change. Since several years, satellite observations of phytoplankton have revealed that phytoplankton concentrations at the surface of the ocean are characterized by a patchy distribution (Gower et al., 1980; Yoder et al., 1987). These patches can be generated by biological processes such as cell buoyancy, behavioral patterns or grazing (Martin, 2003), but also by physical ocean circulation (Strass, 1992). The term "fine scales" refers here to ocean dynamical processes occurring on horizontal scales of the order of 1-100 km and characterized by a small Rossby number and a relative short lifetime from days to weeks. Such ephemeral structures are induced by mesoscale interactions and frontogenesis (McWilliams, 2016). Since the lifetime of fine-scale features is often similar to the phytoplankton growth time scale, this suggests that fine-scale can affect and modulate the phytoplankton community.

The role of fine scales on phytoplankton bulk primary production is now well established. Several fields and modelling studies have shown that fine-scales could generate intense vertical velocities, which transport nutrients from the mixed layer to the euphotic zone, enhancing the phytoplankton production (e.g., Lapeyre and Klein, 2006; Lévy et al., 2001; Pidcock et al., 2016; Mahadevan, 2016). These vertical motions can also limit the phytoplankton growth, subducting phytoplankton cells from the euphotic zone to the deeper layers, before the nutrients are entirely consumed (Lévy et al., 2001). In respect to bulk production, much less is known about the role of the fine scales on phytoplankton diversity. Indeed the effect of the fine scales on phytoplankton diversity has been predominantly studied using numerical simulations (Clayton et al., 2013; Barton et al., 2014; Lévy et al., 2015; Soccodato et al., 2016), while in situ samplings remain challenging because of the ephemeral nature of the dynamical structures. That is why, the few in situ samplings have been principally performed in coastal upwelling regions (Ribalet et al., 2010) and in boundary currents (Clayton et al., 2014, 2017), which generate persistent fronts. These frontal structures associated to intense horizontal transport and vertical velocities (Allen and Smeed, 1996; Rudnick, 1996), can create physical barriers in the surface ocean separating water masses and phytoplankton (Bower and Lozier, 1994). Furthermore, since the work of Yoder et al. (1994) these regions are well-known to be sites of high biological productivity.

More recently the numerical simulations of Barton et al. (2010) have shown that the fine scales may also be hotspots of phytoplankton diversity. In addition, exploiting remote sensing observations, d'Ovidio et al. (2010) have suggested that fronts play a key role in the generation of fluid dynamical niches, by segregating water patches with specific physical and chemical characteristics for time scales long enough for the emergence of a local phytoplanktonic community. It has then been argued that these features, which eventually mix together, can precondition biodiversity hotspots (De Monte et al., 2013; Soccodato et al., 2016). This scenario of a higher phytoplanktonic diversity driven by finescale fronts has recently received some empirical evidence by the comparison of molecular data of diatom diversity with satellite-derived front detections (Busseni et al., 2020).

The large majority of these works however have focused on the extreme situations occurring in boundary currents, whose intense fronts and dramatic contrasts in water properties are not representative of the global ocean. On the contrary, vast oceanic regions are dominated by weak fronts, which are continuously created, moved, and dissipated, and separate water masses with 
https://doi.org/10.5194/bg-2021-38

Preprint. Discussion started: 2 March 2021

(c) Author(s) 2021. CC BY 4.0 License.

\section{(c) (i)}

similar properties. Whether fine-scale fronts maintain their driving role on phytoplankton diversity also in these weaker regions remains therefore an open question which has been largely neglected, due to the difficulty of performing in situ experiments over these short lived features. In this study, we attempt to address this issue in a case study, focusing on a low energetic front and to relate its role on the distribution of phytoplankton groups.

To track the fine-scale ephemeral structures has required the development of new sampling strategies. Utilizing remote sensing and numerical simulations to define the sampling strategy, field studies as LatMix (Shcherbina et al., 2015), AlborEx (Pascual et al., 2017) and LATEX (Petrenko et al., 2017) demonstrated that individual fine-scale features can be experimentally targeted. While these past campaigns focused mainly on physical processes, recent progress in biogeochemical sensors now makes the study of physical-biological coupling easier. Then, the combination of the accumulated experience and the methodological developments allows to perform field studies on physical-biological coupling at fine scale in low-energetic and oligotrophic areas. During the BLUE-FIN-13 cruise, Mena et al. (2016) studied the picophytoplankton distribution in a haline front formation area in the Balearic Sea. More recently, the OSCAHR cruise in the Ligurian Sea was specially designed to combine high-resolution measurements of both physical and biological variables (Doglioli, 2015). Exploiting the large data set collected during this cruise, Marrec et al. (2018) and Rousselet et al. (2019) have shown the influence of physical dynamics in controlling the spatial distribution of phytoplankton through an eddy structure, highlighting the close relationship between fine scale dynamics and the distribution of phytoplankton. In the southwest Pacific ocean, high-resolution biological sampling during OUTPACE (Moutin and Bonnet, 2015) and TONGA (Guieu and Bonnet, 2019) has shown the influence of fronts in controlling the spatial distribution of bacteria and phytoplankton (Rousselet et al., 2019; Benavides et al., 02 October 2020). Recently, the methodological developments in underway nitrogen $\left(\mathrm{N}_{2}\right)$ fixation measurements allowed to capture a rapid shift of the diazotrophic community in the North Atlantic ocean (Tang et al., 2020).

Following a satellite-based adaptive and Lagrangian strategy, a high-resolution coupled physical-biological sampling was performed during the PROTEVSMED-SWOT cruise in the southwestern Mediterranean Sea, south of the Balearic Islands (Dumas, 2018; Garreau et al., 2020). This cruise was operated in the context of the preparation of the new satellite mission Surface Water and Ocean Topography (SWOT; https://swot.jpl.nasa.gov/,https://swot.cnes.fr). This mission is dedicated to provide ocean topography and surface current at an unprecedented resolution, in particular during its fast sampling phase when SWOT will sample some key areas called "cross-overs" twice per day, offering a suitable opportunity to study the physical-biological fine-scale coupling (Morrow et al., 2019; d'Ovidio et al., 2019). The PROTEVSMED-SWOT cruise took place under one of these future cross-overs in the Mediterranean Sea. The large data set obtained during the cruise has been combined with the data collected during the PRE-SWOT cruise performed in coordination and simultaneously with PROTEVSMED-SWOT (Barceló-Llull et al., 2018).

In this paper, we first describe the hydrodynamics and hydrology of the area of study, with a focus on the vertical velocities estimated through the omega equation. Then, we identify the water masses residing in the region during the cruise. Finally, the distribution of various groups of phytoplankton, and of fluorescent dissolved organic matter (FDOM), are presented in rela- 
https://doi.org/10.5194/bg-2021-38

Preprint. Discussion started: 2 March 2021

(c) Author(s) 2021. CC BY 4.0 License.

\section{(c) (i)}

tion to the fine-scale dynamics. An advanced statistical analysis is performed to highlight objectively the physical-biological coupling.

\section{Materials and methods}

\subsection{Satellite-based adaptive sampling strategy}

PROTEVSMED-SWOT took place onboard the RV Beautemps-Beaupré between 30 April and 18 May 2018. During the cruise, an adaptive Lagrangian sampling strategy was possible thanks to SPASSO (Software Package for an Adaptive Satellitebased Sampling for Oceanographic cruises ; https://spasso.mio.osupytheas.fr, last access: 10 February 2021). Various satellite datasets were used during PROTEVSMED-SWOT. Sea surface temperature (SST, levels 3 and 4, $1 \mathrm{~km}$ resolution, not shown in this study) and chlorophyll $a$ concentrations ([Chla], level 3,1 km resolution) were provided by CMEMS (Copernicus Marine Environment Monitoring Service, https://marine.copernicus.eu, last access: 10 February 2021). Moreover ocean color composite maps were provided by CLS with the support from CNES. They are constructed with a simple weighted average over the five previous days of the data issued from the Suomi/NPP/VIIRS sensor. The altimetry-derived geostrophic velocities from AVISO (Archiving, Validation and Interpretation of Satellite Oceanographic) database were exploited to extract near realtime daily maps. These were also used to derive the finite size Lyapunov exponents (FSLEs) by time-integrating trajectories following the algorithm of d'Ovidio et al. (2004) and summarized as follows. Lagrangian numerical particles were initially separated by $0.1^{\circ}$ and reached a final separation of $0.6^{\circ}$. Then, FSLEs were calculated using 30 day backward integration. FSLEs values often form continuous lines, or ridges, which are used to identify regions of enhanced strain that are to be expected near frontal zones.

SPASSO was used to follow both the temporal and spatial variability of the horizontal fine-scale features of interest. SPASSO combines satellite-derived currents, SST and [Chla], to provide maps of dynamical and biogeochemical structures in both Near Real Time (NRT) and Delayed Time (DT). During the cruise the analysis of these maps suggested the presence of two different regions, characterized by their different surface [Chla] (Fig. 1). Consequently, these two regions have been sampled along a dedicated route of the ship, represented in purple and in orange on Fig. 1. A special attention was paid to adapt the temporal sampling in these different water masses to the biological time scales, i.e. trying to catch the diurnal cycle. Because of the shape of the ship track, in the following we refer to these areas as "West-East (WE) hippodrome" (in orange on Fig. 1) performed from 8 May 15:30 to 10 May 17:30 UTC, and "North-South (NS) hippodrome" (in purple on Fig. 1) performed between 11 May 02:00 and 13 May 08:30 UTC.

\subsection{In situ measurements}

Physical and biological variables (horizontal velocities, temperature, salinity, and abundances of the different phytoplankton functional groups) were measured at high frequency all along the route. In situ systems include a Seasoar® deployed at sea, a vessel-mounted Acoustic Doppler Current Profiler (VMADCP), a thermosalinograph (TSG) and a flow cytometer installed on 
https://doi.org/10.5194/bg-2021-38

Preprint. Discussion started: 2 March 2021

(c) Author(s) 2021. CC BY 4.0 License.

\section{(c) (i)}

board. The Seasoar is a towed undulating vehicle capable of achieving undulations from surface down to $400 \mathrm{~m}$. Two Sea-Bird SBE-9 (with SBE-3 temperature and SBE-4 conductivity sensors) instruments mounted on either side of the Seasoar enables the simultaneous measurements of temperature, salinity (from conductivity) and pressure. The conductivity and temperature data were lag-corrected to reduce salinity spiking with the methodology developed by Lueck and Picklo (1990), Morison et al. (1994) and Mensah et al. (2009), before conversion to absolute salinity $\mathrm{S}_{A}$ and conservative temperature $\Theta$, in accordance with TEOS-10 standards (McDougall et al., 2012). In the following, temperature and salinity refer to absolute salinity and conservative temperature. Horizontal velocities between $19 \mathrm{~m}$ and $253 \mathrm{~m}$ have been measured with a VMADCP operating at $150 \mathrm{kHz}$. VMADCP data treatment was performed with the Matlab software Cascade V.7 (https://www.umr-lops.fr/en/ Technology/Software/CASCADE-7.2, last access: 10 February 2021). The sea surface temperature and salinity have been measured continuously along the ship route by the underway TSG. The TSG was equipped with two sensors: i) a CTD sensor SeaBird Electronics SBE 45, installed in the wet lab, connected to the surface water, and pumping continuously seawater at 3 m depth. ii) a temperature sensor SBE 38 installed at the entry of the water intake.

An automated CytoSense flow cytometer (CytoBuoy b.v) was installed on board and connected to the seawater circuit of the TSG, to perform scheduled automated sampling and analysis of phytoplankton (Thyssen et al., 2009, 2015). The instrument contains a sheath fluid made of $0.1 \mu \mathrm{m}$ filtered seawater which stretches the sample in order to separate, align and drive the individual particles (i.e. cells) through a light source. This light source is made of a $488 \mathrm{~nm}$ laser beam. When the particles cross the laser beam, they interact with the photons. Several optical signals are recorded for each single particle: the forward angle light scatter (FWS) and $90^{\circ}$ side-ward angle scatter (SWS), related to the size and the structure (granularity) of the particles. Two signals of fluorescence induced by the light excitation were also recorded, a red fluorescence (FLR) induced by chlorophyll $a$ and an orange fluorescence (FLO) induced by the phycoerythrin pigment. Two distinct protocols have been run sequentially every $30 \mathrm{~min}$, in order to process the 1164 samples. The first protocol (FLR6) has a FLR trigger threshold fixed at $6 \mathrm{mV}$ and is able to analyze a volume of $1.5 \mathrm{~cm}^{3}$. It was dedicated to the analysis of the smaller phytoplankton. For instance, Synechococcus were optimally resolved and counted with this protocol. The second protocol (FLR25), targeted nanophytoplankton and microphytoplankton with FLR trigger level fixed at $25 \mathrm{mV}$ and an analyzed volume of $4 \mathrm{~cm}^{3}$. The data were acquired thanks to the USB software (Cytobuoy b.v.) but analyzed with the CytoClus software (Cytobuoy b.v.). The combination of the various variables recorded by the flow cytometer exhibits various clusters of particles (cells), which abundance (cells per cubic centimetre) and average variable intensities are provided by the CytoCLUS software. The later generates several two-dimensional cytograms (e.g. Fig. 12, see section 3.3 for explanation of the group identification) of retrieved information from the 4 pulse shapes curves (FWS, SWS, FLO, FLR) obtained for every single cell.

On 5 May 2018, a SeaExplorer glider, manufactured by Alseamar (codename: SEA003), was deployed at sea. After a short transit, it performed a route approximately parallel to the NS hippodrome (red track on Fig. 1). This glider, set to dive down to $650 \mathrm{~m}$ depth, was equipped with a pumped conductivity-temperature-depth sensor (Seabird's GPCTD) from which the conservative temperature $(\Theta)$, the absolute salinity $\left(\mathrm{S}_{\mathrm{A}}\right)$ and the density anomaly referenced to the surface $\left(\sigma_{0}\right)$ were derived using TEOS-10 toolbox (McDougall and Barker, 2011). This GPCTD was also equipped with a dissolved oxygen $\left(\mathrm{O}_{2}\right)$ sensor (Seabird's SBE-43F) to measure oxygen concentrations. The glider also embarked a WET Labs ECO Puck FLBBCD for 
https://doi.org/10.5194/bg-2021-38

Preprint. Discussion started: 2 March 2021

(c) Author(s) 2021. CC BY 4.0 License.

(c) (i)

measurements of i) [Chla] fluorescence (targeting excitation and emission wavelengths at $\lambda \mathrm{Ex} / \lambda \mathrm{Em}: 470 / 695 \mathrm{~nm}$ ), converted into Chla concentrations (in microgram per litre), ii) backscattering at $700 \mathrm{~nm}$ (BB700), and iii) a FDOM fluorophore, namely the humic-like fluorophore or peak $C$ in the Coble (1996)'s classification $(\lambda \mathrm{Ex} / \lambda \mathrm{Em}$ : 370/460 nm), expressed in microgram per litre equivalent quinine sulfate units (microgram per litre QSU). Finally, the SeaExplorer was also equiped with two MiniFluo-UV fluorescence sensors (hereafter called MiniFluo) for the detection of various FDOM fluorophores (Cyr et al., 2017, 2019). In this study, the MiniFluo-1 was used for the detection of tryptophan-like fluorophore ( $\lambda \mathrm{Ex} / \lambda \mathrm{Em}$ : $275 / 340$ $\mathrm{nm}$ ), while the MiniFluo-2 was used for the detection of tyrosine-like fluorophore ( $\lambda \mathrm{Ex} / \lambda \mathrm{Em}: 260 / 315 \mathrm{~nm}$ ). Tryptophan- and tyrosine-like fluorophores, referred to as peak T and peak B, respectively, in the Coble (1996)'s classification, are amino acidlike components commonly found in the marine environment, and generally associated with autochthonous biological processes (see review by Coble et al. (2014)). Here, fluorescence intensities of tryptophan- and tyrosine-like fluorophores are provided in relative unit (RU) and are not converted into mass concentration (microgram per litre) (Cyr et al., 2017, 2019). Glider observations were processed with the Socib glider toolbox (Troupin et al., 2015) for cast identification and geo-referencing.

\subsection{Vertical velocity estimation}

The vertical velocity has been diagnosed solving the so-called quasi-geostrophic (QG) omega equation (Hoskins et al., 1978; Tintoré et al., 1991; Allen and Smeed, 1996, Eq. (1)):

$165 \nabla^{2}\left(N^{2} w\right)+f^{2} \frac{\partial^{2} w}{\partial z^{2}}=2 \nabla \cdot \boldsymbol{Q}$

where $w$ is the vertical component of the velocity field and $Q$ is the vector determined by horizontal derivatives of water density and horizontal velocity (Hoskins et al., 1978; Giordani et al., 2006, Eq. (2)):

$\boldsymbol{Q}=\left(\frac{g}{\rho_{0}} \frac{\partial \boldsymbol{V}_{\boldsymbol{g}}}{\partial x} \nabla \rho, \frac{g}{\rho_{0}} \frac{\partial \boldsymbol{V}_{\boldsymbol{g}}}{\partial y} \nabla \rho\right)$

with $\boldsymbol{V}_{\boldsymbol{g}}$ the geostrophic horizontal velocity vector, $\rho$ the density, $\rho_{0}$ a reference density equal to $1025 \mathrm{~kg} \mathrm{~m}^{-3}, g$ the gravitational acceleration, $f$ the Coriolis parameter (considered constant and computed at the mean latitude of the area), and $\mathrm{N}^{2}$ the Brunt-Väisälä frequency. The QG theory is valid for low Rossby numbers, a condition that is satisfied in this study.

High-resolution in situ data are necessary to solve Eq. (1). In this work, $\sigma$ is obtained from Seasoar CTD measurements (Fig. 2) and the geostrophic component of the horizontal velocity has been estimated from the measurements performed with the VMADCP as in the work of Barceló-Llull et al. (2017). Following Allen et al. (2001)'s suggestions to preserve as much as possible synopticity, four transects of the NS hippodrome (see Fig. 1) have been selected between 11 May and 12 May 2018, to obtain a "butterfly" design as in Cotroneo et al. (2016) and Rousselet et al. (2019). The $\sigma$, u and v fields have been interpolated onto a 3D grid, using objective analysis (Le Traon, 1990; Rudnick, 1996). The horizontal grid resolution is $0.9 \mathrm{~km} \times 0.9 \mathrm{~km}$ and the vertical resolution is $6 \mathrm{~m}$ (from $19 \mathrm{~m}$ to $253 \mathrm{~m}$ depth). We have followed the method described by Rudnick (1996), using the scripts freely downloadable from his web page at the address http://chowder.ucsd.edu/Rudnick/SIO_221B.html, last access: 
https://doi.org/10.5194/bg-2021-38

Preprint. Discussion started: 2 March 2021

(c) Author(s) 2021. CC BY 4.0 License.

(c) (i)

10 February 2021. The in situ data are considered to be composed of a mean value, a fluctuation and some noise including both smaller scale variability and instrumental error. The fluctuation part of the field's statistics is assumed to have a decorrelation length scale of $20 \mathrm{~km}$ in both the $\mathrm{x}$ and $\mathrm{y}$ directions, with a structure orientation of $18.4^{\circ}$ from north. The correlation length scale has been chosen by analyzing the auto-covariance matrix of the $\sigma$ field and performing several sensitivity tests. The noise-to-signal ratio is assumed to be 0.05 as in Rudnick (1996). The interpolated fields are shown superposed to the in situ measurements in Fig. 2. The ageostrophic component of the velocity measured by the VMADCP is then removed and Eq. (1) is solved with an iterative relaxation method and constrained by Dirichlet boundary conditions $(w=0)$ as in the case of the front studied by Rudnick (1996). To minimize the effect of the imposed boundary conditions, only data with an error on the objective mapping of $\sigma \leq 0.0025$ have been then considered.

\section{Results}

\subsection{Hydrodynamics}

At first, we describe the hydrodynamic conditions encountered during PROTEVSMED-SWOT in order to characterize the area. For simplicity, two transects only, representative of each of the two hippodromes, are presented: a first transect, on the WE hippodrome, performed from 9 May 16:50 to 23:45 UTC is referred to as the WE transect (Fig. 3a). The second one performed on the NS hippodrome, from 11 May 02:00 to 08:40 UTC, is referred to as the NS transect (Fig. 3b). The horizontal velocities have been measured by VMADCP at $25 \mathrm{~m}$ along both WE and NS transects, and superimposed to the FSLE field for the corresponding date. The intensity and the direction of the current vary along the transects. Around $38^{\circ} \mathrm{N} 20^{\prime}$, a zonal fine scale feature, slowly evolving, is present in the altimetry-derived FSLE field and confirmed by the VMADCP data. At this latitude, the current direction changes drastically along the NS transect. The WE transect shows a larger current variability than the NS transect, due to its alignment with the fine scale structure. The FSLE features and the variation of current direction are likely induced by the presence of a fine scale structure, in this case a front.

Figures $4 \mathrm{a}$ and $4 \mathrm{~b}$ show the vertical velocities estimated at $25 \mathrm{~m}$ and $85 \mathrm{~m}$ depths for the NS hippodrome. The area is characterized by three main features: two upwelling cells (positive values) separated by a downwelling cell (negative values) located between $38^{\circ} \mathrm{N} 30^{\prime}$ and $38^{\circ} \mathrm{N} 36^{\prime}$. Another smaller downwelling patch is present in the south-east of the sampling area. The intensities of these vertical motions, ranging from 2 to $810^{-5} \mathrm{~m} \mathrm{~s}^{-1}$ (corresponding to 1.7 to 6.9 in meter per day), are stronger in the intermediate layer.

\subsection{Hydrology and biogeochemistry}

The typical southwestern Mediterranean water masses are observed in the $\Theta-S_{A}$ diagrams of the Seasoar CTD data of the WE and NS transects (Fig. 5a and Fig. 5c, respectively). A clear separation in two different water masses appears at the surface. In order to objectively identify where these two water masses separate, we first distinguish surface from intermediate waters by the isopycnal at $28.45 \mathrm{~kg} \mathrm{~m}^{-3}$ on the $\Theta-S_{A}$ diagrams. Then, an iterative method with a granularity of $0.05^{\circ}$ in 
https://doi.org/10.5194/bg-2021-38

Preprint. Discussion started: 2 March 2021

(c) Author(s) 2021. CC BY 4.0 License.

\section{(c) (i)}

longitude(latitude) along the WE(NS) transect has been used to calculate the means of the two surface water masses in terms of salinity and temperature, $\left(\overline{S_{A 1}}, \overline{\Theta_{1}}\right)$ and $\left(\overline{S_{A 2}}, \overline{\Theta_{2}}\right)$, and the difference in term of mean salinity, $\left|\overline{S_{A 1}}-\overline{S_{A 2}}\right|$. Then, the best separation between the two surface water masses correspond at the longitude(latitude) along the WE(NS) transect where the maximal difference $\left|\overline{S_{A 1}}-\overline{S_{A 2}}\right|$ is found. Table 1 summarizes the maximal differences calculated for the transects of the WE and NS hippodromes performed with the Seasoar and the associated localisations of the best separation. Only one transect of the WE hippodrome is shown, because we deplore a lack of data in the Seasoar measurement during the other transects of this hippodrome. Along the WE transect the surface water masses separate at longitude $4^{\circ}$ E 06', while along the NS transect separate at the latitude $38^{\circ} \mathrm{N} 32^{\prime}$. Note that for the other meridional transects the estimate separation varies of only few minutes. $\Theta-S_{A}$ diagrams (Fig. 5a and Fig. 5c), and their associated maps (Fig. 5b and Fig. 5d), correspond to the WE and the NS transects described in the previous section 3.1. The maps shown in Fig. 5b and Fig. 5d indicate the geographical positions of the two types of $\mathrm{AW}$, using the same color code as in the $\Theta-S_{A}$ diagrams. Interpretation of these data is the following. The surface layer is occupied by Atlantic Waters (AW) with different residence times in the Mediterranean Sea. We refer to them as "younger AW" (in light blue) and "older AW" (in dark blue). The "younger AW" corresponds to AW entered more recently in the Mediterranean basin and is characterized by a salinity between $37 \mathrm{~g} \mathrm{~kg}^{-1}$ and $38 \mathrm{~g} \mathrm{~kg}^{-1}$, while the "older AW" is characterized by a higher salinity. Indeed, this AW has been modified during its circulation in the Mediterranean Sea: its salinity has increased due to evaporation and mixing. Other authors refer to this water as "local AW" (Barceló-Llull et al., 2019) or "resident AW" (Balbín et al., 2012). The "younger AW" is located at the west and at the south of the WE and NS transects, respectively. Moreover, the separation between the two types of AW is in agreement with the localisation of the front identified by the FSLE and the change in current direction (Fig. 3). Below the surface layer, the intermediate water is more homogeneous and is characterized by a temperature of $13-14{ }^{\circ} \mathrm{C}$ and a salinity of $38-38.5 \mathrm{~g} \mathrm{~kg}^{-1}$ (in pink on Fig. 5a and Fig. $5 \mathrm{c})$.

The SeaExplorer glider has also performed temperature and salinity measurements along a transect parallel and slightly west of the NS hippodrome (see Fig. 1). The $\Theta-S_{A}$ diagrams of the glider data (Fig. 6a and Fig. 6b) confirm the presence of the two surface water masses mentioned above, in particular during the outward route (Fig. 6a). During the glider return route (Fig. 6b) the surface water masses begin to be more homogeneous than during the outward route and the NS Seasoar transect (Fig. 5c). This fact can be explained because the transects completed with the Seasoar were realized within a few hours, while the glider transects lasted several days. Moreover, the deeper glider sampling has allowed to detect another thermohaline signature, with temperature values about $13{ }^{\circ} \mathrm{C}$ and salinity ranging around $38.5 \mathrm{~g} \mathrm{~kg}^{-1}$, which corresponds to the Western Mediterranean Deep Water (WMDW) as found by Balbín et al. (2012).

The vertical extension of the surface and intermediate water masses can be observed plotting the Seasoar data (conservative temperature, absolute salinity and density) as vertical sections along the WE (Fig. 7) and NS transects (Fig. 8). The warm surface layer with temperature greater than $15{ }^{\circ} \mathrm{C}$ extends until about $100 \mathrm{~m}$. This layer is also characterized by a salinity between $37.5 \mathrm{~g} \mathrm{~kg}^{-1}$ and $38 \mathrm{~g} \mathrm{~kg}^{-1}$ and, as a consequence, by the lowest density. Below $100 \mathrm{~m}$ depth there is the intermediate water layer. Looking at gradients along the transects we can clearly identify the separation between the two types of AW at 
https://doi.org/10.5194/bg-2021-38

Preprint. Discussion started: 2 March 2021

(c) Author(s) 2021. CC BY 4.0 License.

\section{(c) (i)}

longitude $4^{\circ} \mathrm{E}$ for the WE transect (Fig. 7) and latitude $38^{\circ} \mathrm{N} 30^{\prime}$ for the NW transect (Fig. 8), as obtained with the iterative method.

The vertical sections of concentrations in chlorophyll $a$ ([Chla]) and oxygen $\left[\mathrm{O}_{2}\right]$, issued from the SeaExplorer glider measurements along the outward route (Fig. 9) and the return route (Fig. 10) show the richness of the structures present in the first $250 \mathrm{~m}$ of the water column. For the two transects, the deep chlorophyll maximum (DCM) was generally present between 50 and $100 \mathrm{~m}$ depth.

Overall, [Chla] is higher in "older AW" (located north of $38^{\circ} \mathrm{N} 30^{\prime}$ ) than in "younger AW" (located south of $38^{\circ} \mathrm{N} 30^{\prime}$ ). Approximately at this latitude a deepening of the maximum of [Chla] is present, probably associate with the vertical dynamics of the front. Similar patterns are also observed in the $\left[\mathrm{O}_{2}\right]$ data, that confirm a possible downwelling of the surface waters at the front location, but also indicate a deeper oxygenation of the "older $\mathrm{AW"}$ ", as observed during the return route.

The vertical sections of peak B and peak T (respectively tyrosine- and tryptophan-like fluorophores) fluorescence intensities revealed distribution patterns very close to that of [Chla] for peak $\mathrm{B}$, and very close to that of $\left[\mathrm{O}_{2}\right]$ for peak $\mathrm{T}$ (data not shown). These similarities in the profiles were confirmed by correlation analyses (Fig. 11), which pointed out a very highly significant linear positive correlation between [Chla] and peak $\mathrm{B}$, and between $\left[\mathrm{O}_{2}\right]$ and peak $\mathrm{T}$ when considering all glider data for the two transects from 5 to $200 \mathrm{~m}$ depth $(\mathrm{r}=0.88$ and $0.84, \mathrm{n}=\approx 32595, \mathrm{p}<0.0001)$. In addition, these patterns and correlations emphasized different origins for these two FDOM fluorophores, albeit they are both related, directly or indirectly, to phytoplankton activity.

\subsection{Characterization and distribution of phytoplankton by flow cytometry}

Up to nine phytoplankton groups were optically resolved by flow cytometry (Fig. 12), thanks to their light scatter (forward scatter, FWS, and sideward scatter, SWS) and their fluorescence properties (intensity in red, FLR, and in orange, FLO). The first group, corresponding to Synechococcus (Syn), is characterized by a higher FLO intensity compared to the FLR intensity (Fig. 12c), induced by the presence of phycoerythrin pigments. A first eukaryotic picophytoplankton group (Pico1) shows lower FLR and FLO intensities than Synechococcus (Fig. 12c). Two other groups of picophytoplankton (Pico2 and Pico3) exhibit higher FWS, SWS and FLR intensities than Pico1 (Fig. 12d). The last group of picophytoplankton (PicoHFLR) is characterized by a high FLR signal induced by Chla. Two distinct nanophytoplankton groups (SNano) and (RNano) were defined according to their high FLR and FLO intensities (Fig. 12a and Fig. 12c). SNano have a high SWS/FWS ratio and higher SWS intensities than RNano (Fig. 12b) and Fig. 12a). Finally, microphytoplankton (Micro) and Cryptophytes (Crypto) exhibit high FLR and FLO intensities (Fig. 12c). The size and the abundances of these groups have been summarized in Table 2. In Table 2 and on Fig. 13 and 14, the abundances of nanophytoplankton and picophytoplankton represent the sum of the abundances of the various groups of eukaryotic nanophytoplankton (RNano and SNano) and eukaryotic picophytoplankton (Pico1, Pico2, Pico3 and PicoHFLR), respectively.

Figures 13 and 14 show the surface abundances of the various phytoplankton groups, along the WE and the NS transects. Synechococcus (Fig. 13a and Fig. 14a) and Picophytoplankton (Fig. 13b and Fig. 14b) presented a similar distribution pattern. High abundances around 2.2-3.0 $10^{4}$ cells cm${ }^{-3}$ and 3.6-4.5 $10^{3} \mathrm{cells} \mathrm{cm}^{-3}$, recorded respectively for Synechococcus and for 
https://doi.org/10.5194/bg-2021-38

Preprint. Discussion started: 2 March 2021

(c) Author(s) 2021. CC BY 4.0 License.

\section{(c) (i)}

Picophytoplankton, are located at the western and southern parts of the front, along with the WE and the NS transects. On

the other side of the front, their abundances are lower, $\left(\leq 110^{4}\right.$ cells cm ${ }^{-3}$ for Synechococcus and $\sim 210^{3}$ cells cm$^{-3}$ for Picophytoplankton). Microphytoplankton abundances vary between $8-18 \mathrm{cells} \mathrm{cm}^{-3}$ (Fig. 13c and Fig. 14c) and present an opposite distribution with the previous groups. Indeed, higher abundances are found in the eastern and northern parts of the front. Nanophytoplankton (Fig. 13d and Fig. 14d) and Cryptophytes (Fig. 13e and Fig. 14e) ranged from 650-1000 cells cm ${ }^{-3}$ and $10-30$ cells cm $^{-3}$ respectively. However, these latter exhibited a less clear pattern between the two sides of the front. The distribution of the abundances of phytoplankton between the front (specially observed for Synechococcus, Picophytoplankton and Microphytoplankton) fits well with the hydrodynamic and the hydrological observations.

\subsection{Statistical analysis}

Surface temperature and salinity data measured with the TSG are merged with the data of abundances of the 9 different groups of phytoplankton at each cytometry sampling point along the WE and NS hippodromes. Thus, the final data set consists of 11 variables, each variable containing 215 observations.

The principal component analysis (PCA) consists of summarizing the information contained in the data set by replacing the initial variables with new synthetic variables (called principal components), linear combinations of the initial variables and uncorrelated two by two. Applied to our data set, the PCA points out that the first three components explain respectively $36.7 \%, 18.1 \%$ and $13 \%$ of the total variance of the data. The following statistical analysis treats these three components, representing $67.8 \%$ of the total variance of the data. Figure 15a shows positively correlated variables grouped together in the first factorial plane: salinity $\left(\mathrm{S}_{A}\right)$ with microphytoplankton (Micro); Synechococcus (Syn) with picophytoplankton Pico1 group; picophytoplankton Pico2 group and nanophytoplankton RNano group; temperature $(\Theta)$ with picophytoplankton Pico3 group and nanophytoplankton SNano group. However, Cryptophytes (Crypto) group and picophytoplankton PicoHFLR group are not as well correlated with the other variables compared to the other groups of phytoplankton.

The K-medoid algorithm, described by Hartigan and Wong (1979); Kaufman and Rousseeuw (1987), is an other method to represent the various aspects of the data structure. This algorithm divides $\mathrm{M}$ points in $\mathrm{N}$ dimensions into $\mathrm{K}$ groups (or clusters). A cluster is an object for which the average dissimilarity to all the data is minimal. In our case of study, the K-medoid algorithm divides the 215 points into three clusters in two dimensions (Fig. 15b). Each point of a cluster shows a high degree of similarity with the others points of the same cluster. The three clusters are well separated. Only a few points of the black and red clusters are difficult to disentangle. Finally, the average of each variable, called local average, has been calculated for each cluster, as well as the global average, to show the contribution of each variable to a cluster. The most discriminating variables for each cluster (Table 3) have also been determined with the standard deviation.

Figure $15 \mathrm{c}$ is a spatio-temporal representation of the three main clusters obtained by the K-medoid algorithm. The WE hippodrome from 8 to 10 May is characterized by the presence of the black cluster in the east and the red cluster in the west. The NS hippodrome starts the 11 May with the red cluster present in the south and the black cluster in the north. The latter remains dominant in the north for the remaining of the sampling. In the south, the red cluster is gradually replaced by the blue cluster, except a few points on the 13 May. 
https://doi.org/10.5194/bg-2021-38

Preprint. Discussion started: 2 March 2021

(c) Author(s) 2021. CC BY 4.0 License.

\section{(c) ${ }_{\mathrm{BY}}$}

In Fig. 15d the geographical distribution of the three clusters is shown superposed on the FSLE field. A general good agreement is observed between the shifts of different clusters and the FSLE maxima. In particular, the separation between the black and red clusters at around $4^{\circ} \mathrm{E}$ on the WE hippodrome corresponds to the two FSLE maxima crossing this longitude at $38^{\circ} \mathrm{N} 40^{\prime}$ and at $38^{\circ} \mathrm{N} 20^{\prime}$. On the NS hippodrome, the black cluster is separated from the two others at about $38^{\circ} \mathrm{N} 20^{\prime}$ where zonally-disposed FSLE maxima cross the vessel route. To summarize, the black cluster dominates in the north of the sampled area, while in the south the red cluster is dominant at the beginning and then replaced by the blue cluster. The separation between the clusters can be explained by the distribution of the maxima of the FSLE field, i.e. in terms of fine-scale dynamics. Given the ephemeral nature of these latter processes, the temporal evolution of the distribution of the red and blue cluster is probably due to the displacement of the frontal structure.

\section{Discussion and conclusion}

For the case of energetic open ocean regions, like boundary current systems, model-based analysis, remote sensing and some in situ studies have all shown that the fine scales can modulate the phytoplankton growth and diversity (e.g., d'Ovidio et al., 2010; Barton et al., 2014; Clayton et al., 2014; Mahadevan, 2016; Lévy et al., 2018). The typical mechanisms suggested for this coupling effect is a barrier effect at fronts associated to intense vertical velocities. However, large part of the ocean is characterized by weaker circulation, and hence by weaker transport barriers and vertical velocities. The impact of these moderately energetic fine-scale structures on phytoplankton communities has not yet been fully evaluated. In particular, their role on phytoplankton diversity deserve closer study. In this work, we have considered a front in the south of the Balearic Islands, in order to provide a view of the physical forcing occurring in this structure and its effect on the distribution of phytoplankton groups.

In Fig. 16, we have summarized the findings of this study. The strong variation of current direction observed in the horizontal velocities measured by VMADCP data and the analysis of the ocean color images combined with the altimetry-derived FSLE field have allowed to identify a frontal area located at the latitude of about $38^{\circ} \mathrm{N} 30^{\prime}$ and between $3^{\circ} \mathrm{E}$ and $4^{\circ} \mathrm{E}$ of longitude. The data from the CTD sensors mounted on the Seasoar towed fish and on the SeaExplorer ocean glider identify a rapid shift between two different types of surface water masses on the $\Theta-S_{A}$ diagrams (Fig. 5 and Fig. 6). These water masses are considered AW at different stages of its circulation path in the western Mediterranean basin. Indeed, AW entering the Mediterranean through the Strait of Gibraltar is forced by the combination of the Coriolis effect and the presence of coasts to form an anticlockwise circulation along the continental slope of the western Mediterranean (Millot, 1999; Millot et al., 2006). South of this basin, the circulation is dominated by the Algerian Current (AC). The AC can become unstable due to baroclinic and barotropic instabilities (e.g., Millot, 1999). Then, meanders of AC, that can also form mesoscale eddies, spread over the basin and join the region south of Balearic Islands. There, the recently entered AW encounters the surface water coming from the north after its complete cyclonic circulation around the western Mediterranean basin. In the studied region, the presence of this water has already observed by Balbín et al. (2012) which refers to it as "resident" AW to indicate the colder and saltier AW of the Balearic Sea, that has remained longer in the Mediterranean. More recently, Cotroneo et al. (2016), Aulicino et al. 
https://doi.org/10.5194/bg-2021-38

Preprint. Discussion started: 2 March 2021

(c) Author(s) 2021. CC BY 4.0 License.

(c) ${ }_{\mathrm{Br}}$

(2018) in the Algerian Basin, and Barceló-Llull et al. (2019) in the Mallorca Channel have revealed the presence of several water masses of AW at different stages of mixing, including the intermediate water and the WMDW that were also detected here.

Our estimation of vertical velocities with the omega equation method allowed to investigate the vertical dynamics in the frontal area (Fig. 4). Several previous studies have shown the importance of fine-scale dynamics in generating vertical velocities (e.g., Rudnick, 1996; Lapeyre and Klein, 2006; Mahadevan and Tandon, 2006; Balbín et al., 2012). Although the ship route was designed mainly for the cytometry sampling across the front, we obtained a spatial grid sufficiently regular to apply the omega equation method, as recommended by Allen et al. (2001). In the area where our sampling with the Seasoar overlaps with the CTD casts performed on a $10 \mathrm{~km}$ spaced regular grid by Barceló-Llull et al. (2018), the respective estimations of the vertical velocity field are in good agreement (Barceló-Llull and Pascual). As our sampling extends further south with respect to the one of Barceló-Llull et al. (2018), we were also able to observe the shift in the current direction, from eastward to westward, and the associated vertical recirculation pattern. Vertical velocities associated with the front are in the order of few meter per day. These values are of the same order of magnitude as the velocities associated with a frontal structure reported by Balbín et al. (2012) in the north-west of the Balearic islands, and by Ruiz et al. (2019) in the Alboran Sea.

During the cruise, the satellite-derived surface [Chla] showed contrasted values between the south-west and the north-east of the studied area (Fig. 1). Thanks to the flow cytometry measurements, we identified several groups of phytoplankton that showed contrasted abundances across the front, in particular the two main groups: Synechococcus and Microphytoplankton. This confirms the results of previous modelling (e.g., Lévy and Martin, 2013; Lévy et al., 2015, 2018), remote-sensing (d'Ovidio et al., 2010) and in situ studies (Clayton et al., 2014), suggesting that frontal structures can act as barriers in the surface ocean, structuring the spatial distribution of phytoplankton. We observed high abundances of Synechococcus and picophytoplankton south of the front, while Microphytoplankton is more abundant north of it. In the Balearic Sea, Mena et al. (2016) already found higher abundances of Synechococcus in the "new" AW than in the "resident" one. In our study, thanks to a much higher resolution and to the omega equation estimations, we can also point out the role of vertical velocity: the smaller and more adaptive organisms dominate in poorer descending water, while larger organisms benefit from enriched upwelled waters. Mena et al. (2019) observed a dominance of Synechoccocus at the surface whereas the other phytoplankton groups were most abundant in the DCM zone. Unfortunately, the fluorometer mounted on the Seasoar fish did not work during the cruise, but we have the data from the one mounted on the the SeaExplorer glider, together with the $\left[\mathrm{O}_{2}\right]$, tryptophan- and tyrosine-like fluorophores sensors. The glider vertical sections (see Fig. 9 and Fig. 10) show patterns that can be explained by the vertical movement of the water masses. For example, the deepening of the DCM is associated with an oxygenation of the subsurface waters, occurring at around $38^{\circ} \mathrm{N} 30^{\prime}$ where a zone of downward vertical velocity is estimated with the omega equation method. These glider data support the identification of the different types of water masses, with "older" AW in the north (displaying higher contents in Chla, $\mathrm{O}_{2}$ and FDOM fluorophores), and "younger" AW in the south (with lower contents in Chla, $\mathrm{O}_{2}$ and FDOM fluorophores), separated by the front zone (see Fig. 11).

Finally, the statistical analysis, coupled with the FSLE Lagrangian diagnostics, proved very useful in synthesizing the physical and biological information and in identifying objectively the role of the front on the distribution of various groups of 
https://doi.org/10.5194/bg-2021-38

Preprint. Discussion started: 2 March 2021

(c) Author(s) 2021. CC BY 4.0 License.

(c) (i)

phytoplankton.

In conclusion, we can say that our results, obtained thanks to an adaptive Lagrangian strategy and high-resolution coupled physical-biological sampling provide an in situ confirmation of the findings obtained by previous modelling studies (e.g., Lévy et al., 2018) and remote sensing (d'Ovidio et al., 2010) about the structuring effect of the fine-scale ocean dynamics on the community structure of the surface phytoplankton community. Furthermore, our results are consistent with the work of Clayton et al. $(2014,2017)$ in an analysis of the phytoplankton accross the Kurushio front, and confirm that ubiquitous and less energetic fronts than those found in boundary currents have a similar impact on the diversity of phytoplankton.

In the future, a better understanding of the biogeochemical processes generating this observed fine-scale physical-biological coupling is needed. In particular, we plan to estimate the growth rate of the phytoplankton cells thanks to the data collected in Lagrangian manner and applying a method similar to the one by Marrec et al. (2018). Moreover, the role of nutrient supply and of zooplankton grazing are key factors in explaining the differences in abundances of the different phytoplankton groups. To address these latter points, future cruises will need high-resolution (and also high-precision, considering the oligotrophy of the Mediterranean Sea) nutrient measurements coupled with zooplankton sampling and dedicated experiment about its grazing on the different phytoplankton groups. Finally, this study also shows how the satellite information is extremely useful for the design of the cruise sampling strategy and, then, for the on-shore post-cruise interpretation of the data. The new satellite SWOT (https://swot.jpl.nasa.gov/, last access: 10 February 2021 ; https://swot.cnes.fr, last access: 10 February 2021) will provide ocean topography and surface current at an unprecedented resolution (Morrow et al., 2019). In particular during the few months after its launch, the period called "fast sampling phase", the satellite will be on a special orbit that will overfly a portion of the global ocean, called "cross-overs", where high spatial resolution will be associated with high temporal resolution (d'Ovidio et al., 2019). Thus, the large data set collected during PROTEVSMED-SWOT represents precious new information on the cross-over area located in the south of the Balearic Islands. Furthermore, our work paves the way to future cruises, planned in this area which will be a great opportunity to study in more detailed way the physical-biological fine-scale coupling.

Code availability. The LATEXtools can be openly available: https://people.mio.osupytheas.fr/ doglioli/latextools.htm, last access: 10 February 2021 (Doglioli et al., 2013).

The script for objective mapping can be openly available on Rudnick’s web page: http://chowder.ucsd.edu/Rudnick/SIO_221B.html, last access: 10 February 2021.

Data availability. The data can be openly available: https://www.seanoe.org/data/00512/62352/, last access: 10 February 2021 (Dumas et al., 2018). 
https://doi.org/10.5194/bg-2021-38

Preprint. Discussion started: 2 March 2021

(c) Author(s) 2021. CC BY 4.0 License.

(c) (1)

410 Author contributions. RT post-processed the in situ observations, performed the analysis of the results and leaded the writing of the manuscript. FD, AMD, GG, PG collected the in situ data. AAP, SB and FdO provided on land support to the sampling strategy. LI and MTh carried out the analysis of flow cytometry data. AP and BBL contributed to the vertical velocity analysis. FC, NB and MTe conducted the glider deployment and the processing of its data. All the authors discussed the results and contributed to the writing of the manuscript.

Competing interests. The authors declare that they have no conflict of interest.

415 Acknowledgements. This work was supported by the CNES in the framework of the project BIOSWOT-AdAC, and by the MIO Axes Transverses program (AT-COUPLAGE). The chlorophyll $a$ product is produced by CLS. The authors thank the SHOM and the crew of the RV Beautemps-Beaupré for shipboard operations, J.-L. Fuda for his help in Seasoar data treatment, L. Rousselet for discussion about vertical velocity estimations, and M. Goutx for the early discussions about the glider FDOM data. The Cytobuoy® flow cytometer was funded by the CHROME project, Excellence Initiative of Aix-Marseille University - A*MIDEX, a French "Investissements d'Avenir" program. SPASSO

420 is operated and developed with the support of the SIP (Service Informatique de Pythéas) and in particular C. Yohia, J. Lecubin. D. Zevaco and C. Blanpain (Institut Pythéas, Marseille, France). The project leading to this publication has received funding from European FEDER Fund under project 1166-39417. R. Tzortzis is financed by a MENRT PhD grant (École Doctorale Sciences de l'environnement - ED 251, Aix-Marseille University). 
https://doi.org/10.5194/bg-2021-38

Preprint. Discussion started: 2 March 2021

(c) Author(s) 2021. CC BY 4.0 License.

(c) (i)

\section{References}

Allen, J. and Smeed, D.: Potential vorticity and vertical velocity at the Iceland-Faeroes front, J. Phys. Oceanogr., 26, 2611-2634, https://doi.org/10.1175/1520-0485(1996)026<2611:PVAVVA>2.0.CO;2, 1996.

Allen, J. T., Smeed, D. A., Nurser, A. J. G., Zhang, J. W., and Rixen, M.: Diagnosis of vertical velocities with the QG omega equation: an examination of the errors due to sampling strategy, Deep-Sea Res. Pt. I, 48, 315-346, https://doi.org/10.1016/S0967-0637(00)00035-2, 2001.

Aulicino, G., Cotroneo, Y., Ruiz, S., Román, A. S., Pascual, A., Fusco, G., Tintoré, J., and Budillon, G.: Monitoring the Algerian Basin through glider observations, satellite altimetry and numerical simulations along a SARAL/AltiKa track, J. Marine Syst., 179, 55-71, https://doi.org/10.1016/j.jmarsys.2017.11.006, 2018.

Balbín, R., Flexas, M. d. M., López-Jurado, J. L., Peña, M., Amores, A., and Alemany, F.: Vertical velocities and biological consequences at a front detected at the Balearic Sea, Cont. Shelf. Res., 47, 28-41, https://doi.org/10.1016/j.csr.2012.06.008, 2012.

Barceló-Llull, B. and Pascual, A.: Uncovering fine-scale ocean currents from in situ observations to anticipate SWOT satellite mission capabilities., in preparation for Front. Mar. Sci.

Barceló-Llull, B., Pallàs-Sanz, E., Sangrà, P., Martínez-Marrero, A., Estrada-Allis, S. N., and Arístegui, J.: Ageostrophic secondary circulation in a subtropical intrathermocline eddy, J. Phys. Oceanogr., 47, 1107-1123, https://doi.org/10.1175/JPO-D-16-0235.1, 2017.

Barceló-Llull, B., Pascual, A., Día-Barroso, L., Sánchez-Román, A., Casas, B., Muñoz, C., Torner, M., Alou-Font, E., Cutolo, E., Mourre, B., et al.: PRE-SWOT Cruise Report. Mesoscale and sub-mesoscale vertical exchanges from multi-platform experiments and supporting modeling simulations: anticipating SWOT launch (CTM2016-78607-P), Tech. rep., CSIC-UIB-Instituto Mediterràneo de Estudios Avanzados (IMEDEA), Madrid, Spain, https://doi.org/10.20350/digitalCSIC/8584, 2018.

Barceló-Llull, B., Pascual, A., Ruiz, S., Escudier, R., Torner, M., and Tintoré, J.: Temporal and spatial hydrodynamic variability in the Mallorca channel (western Mediterranean Sea) from 8 years of underwater glider data, J. Geophys. Res.-Oceans, 124, 2769-2786, https://doi.org/10.1029/2018JC014636, 2019.

Barton, A. D., Dutkiewicz, S., Flierl, G., Bragg, J., and Follows, M. J.: Patterns of diversity in marine phytoplankton, Science, 327, 15091511, https://doi.org/10.1126/science.1184961, 2010.

Barton, A. D., Ward, B. A., Williams, R. G., and Follows, M. J.: The impact of fine-scale turbulence on phytoplankton community structure, Limnology and oceanography: fluids and environments, 4, 34-49, https://doi.org/10.1215/21573689-2651533, 2014.

Benavides, M., Conradt, L., Bonnet, S., Berman-Frank, I., Barrillon, S., Petrenko, A., and Doglioli, A. M.: Fine scale sampling unveils diazotroph patchiness in the South Pacific Ocean, bioRxiv [preprint], https://doi.org/10.1101/2020.10.02.323808, 02 October 2020.

Bower, A. S. and Lozier, M. S.: A closer look at particle exchange in the Gulf Stream, J. Phys. Oceanogr., 24, 1399-1418, https://doi.org/10.1175/1520-0485(1994)024<1399:ACLAPE>2.0.CO;2, 1994.

Busseni, G., Caputi, L., Piredda, R., Fremont, P., Hay Mele, B., Campese, L., Scalco, E., de Vargas, C., Bowler, C., d'Ovidio, F., Zingone, A., Ribera d'Alcalà, M., and Iudicone, D.: Large scale patterns of marine diatom richness: Drivers and trends in a changing ocean, Global Ecol. Biogeogr., 29, 1915-1928, https://doi.org/10.1111/geb.13161, 2020.

Clayton, S., Dutkiewicz, S., Jahn, O., and Follows, M. J.: Dispersal, eddies, and the diversity of marine phytoplankton, Limnology and Oceanography: Fluids and Environments, 3, 182-197, https://doi.org/10.1215/21573689-2373515, 2013.

Clayton, S., Nagai, T., and Follows, M. J.: Fine scale phytoplankton community structure across the Kuroshio Front, J. Plankton. Res., 36, 1017-1030, https://doi.org/10.1093/plankt/fbu020, 2014. 
https://doi.org/10.5194/bg-2021-38

Preprint. Discussion started: 2 March 2021

(c) Author(s) 2021. CC BY 4.0 License.

(c) (i)

Clayton, S., Lin, Y.-C., Follows, M. J., and Worden, A. Z.: Co-existence of distinct Ostreococcus ecotypes at an oceanic front, Limnol. Oceanogr., 62, 75-88, https://doi.org/10.1002/lno.10373, 2017.

Coble, P. G.: Characterization of marine and terrestrial DOM in seawater using excitation-emission matrix spectroscopy, Mar. Chem., 51, 325-346, https://doi.org/10.1016/0304-4203(95)00062-3, 1996.

465 Coble, P. G., Lead, J., Baker, A., Reynolds, D. M., and Spencer, R. G. M.: Aquatic organic matter fluorescence, Cambridge University Press, New York, 2014.

Cotroneo, Y., Aulicino, G., Ruiz, S., Pascual, A., Budillon, G., Fusco, G., and Tintoré, J.: Glider and satellite high resolution monitoring of a mesoscale eddy in the algerian basin: Effects on the mixed layer depth and biochemistry, J. Marine Syst., 162, 73-88, https://doi.org/10.1016/j.jmarsys.2015.12.004, 2016.

Cyr, F., Tedetti, M., Besson, F., Beguery, L., Doglioli, A. M., Petrenko, A. A., and Goutx, M.: A new glider-compatible optical sensor for dissolved organic matter measurements: test case from the NW Mediterranean Sea, Front. Mar. Sci., 4, 89, https://doi.org/10.3389/fmars.2017.00089, 2017.

Cyr, F., Tedetti, M., Besson, F., Bhairy, N., and Goutx, M.: A Glider-Compatible Optical Sensor for the Detection of Polycyclic Aromatic Hydrocarbons in the Marine Environment, Front. Mar. Sci., 6, 110, https://doi.org/10.3389/fmars.2019.00110, 2019.

475 De Monte, S., Soccodato, A., Alvain, S., and d'Ovidio, F.: Can we detect oceanic biodiversity hotspots from space?, ISME J., 7, 2054-2056, https://doi.org/10.1038/ismej.2013.72, 2013.

Doglioli, A.: OSCAHR cruise, RV Téthys II, https://doi.org/10.17600/15008800, 2015.

Doglioli, A. M., Nencioli, F., Petrenko, A. A., Rougier, G., Fuda, J.-L., and Grima, N.: A software package and hardware tools for in situ experiments in a Lagrangian reference frame, J. Atmos. Ocean. Technol., 30, 1940-1950, https://doi.org/10.1175/JTECH-D-12-00183.1, 2013.

d'Ovidio, F., Fernández, V., Hernández-García, E., and López, C.: Mixing structures in the Mediterranean Sea from finite-size Lyapunov exponents, Geophys. Res. Lett., 31, https://doi.org/10.1029/2004GL020328, 2004.

d'Ovidio, F., De Monte, S., Alvain, S., Dandonneau, Y., and Lévy, M.: Fluid dynamical niches of phytoplankton types, Proc. Nat. Acad. Sci. USA, 107, 18 366-18 370, https://doi.org/10.1073/pnas.1004620107, 2010.

d'Ovidio, F., Pascual, A., Wang, J., Doglioli, A., Jing, Z., Moreau, S., Grégori, G., Swart, S., Speich, S., Cyr, F., et al.: Frontiers in Fine-Scale in situ Studies: Opportunities During the SWOT Fast Sampling Phase, Front. Mar. Sci., 6, 168, https://doi.org/10.3389/fmars.2019.00168, 2019.

Dumas, F.: PROTEVSMED_SWOT_2018_LEG1 cruise, RV Beautemps-Beaupré, https://doi.org/10.17183/protevsmed_swot_2018_leg1, 2018.

Dumas, F., Garreau, P., Louazel, S., Correard, S., Fercoq, S., Le Menn, M., Serpette, A., Garnier, V., Stegner, A., Le Vu, B., Doglioli, A., and Gregori, G.: PROTEVS-MED field experiments: Very High Resolution Hydrographic Surveys in the Western Mediterranean Sea, SEANOE [data set], https://doi.org/10.17882/62352, 2018.

Garreau, P., Dumas, F., Louazel, S., Correard, S., Fercocq, S., Le Menn, M., Serpette, A., Garnier, V., Stegner, A., Le Vu, B., et al.: PROTEVSMED field experiments: very high resolution hydrographic surveys in the Western Mediterranean Sea, Earth. Syst. Sci. Data, 12, 441-456, https://doi.org/10.5194/essd-12-441-2020, 2020.

Giordani, H., Prieur, L., and Caniaux, G.: Advanced insights into sources of vertical velocity in the ocean, Ocean Dynam., 56, 513-524, https://doi.org/10.1007/s10236-005-0050-1, 2006. 
https://doi.org/10.5194/bg-2021-38

Preprint. Discussion started: 2 March 2021

(c) Author(s) 2021. CC BY 4.0 License.

(c) (i)

Gower, J., Denman, K., and Holyer, R.: Phytoplankton patchiness indicates the fluctuation spectrum of mesoscale oceanic structure, Nature, 288, 157-159, https://doi.org/10.1038/288157a0, 1980.

500 Guieu, C. and Bonnet, S.: TONGA 2019 cruise, RV L'Atalante., https://doi.org/10.17600/18000884, 2019.

Hartigan, J. A. and Wong, M. A.: Algorithm AS 136: A K-Means Clustering Algorithm, J. Roy. Stat. Soc. C-App., 28, 100-108, https://doi.org/10.2307/2346830, http://www.jstor.org/stable/2346830, 1979.

Hoskins, B., Draghici, I., and Davies, H.: A new look at the w-equation, Quart. J. Roy. Meteorol. Soc., 104, 31-38, https://doi.org/10.1002/qj.49710443903, 1978.

Kaufman, L. and Rousseeuw, P.: Statistical data analysis based on the L1-norm and related methods, Clustering by means of medoids. North-Holland, pp. 405-416, 1987.

Lapeyre, G. and Klein, P.: Impact of the small-scale elongated filaments on the oceanic vertical pump, J. Mar. Res., 64, 835-851, https://doi.org/10.1357/002224006779698369, 2006.

Le Traon, P.: A method for optimal analysis of fields with spatially variable mean, J. Geophys. Res.-Oceans, 95, 13543-13547, https://doi.org/10.1029/JC095iC08p13543, 1990.

Lévy, M. and Martin, A.: The influence of mesoscale and submesoscale heterogeneity on ocean biogeochemical reactions, Global Biogeochem. Cy., 27, 1139-1150, https://doi.org/10.1002/2012GB004518, 2013.

Lévy, M., Klein, P., and Treguier, A.-M.: Impact of sub-mesoscale physics on production and subduction of phytoplankton in an oligotrophic regime, J. Mar. Res., 59, 535-565, https://doi.org/10.1357/002224001762842181, 2001.

515 Lévy, M., Jahn, O., Dutkiewicz, S., Follows, M. J., and d'Ovidio, F.: The dynamical landscape of marine phytoplankton diversity, J. Roy. Soc. Interface, 12, 20150481 , https://doi.org/10.1098/rsif.2015.0481, 2015.

Lévy, M., Franks, P., and Smith, K.: The role of submesoscale currents in structuring marine ecosystems, Nat. Commun., 9, 4758, https://doi.org/10.1038/s41467-018-07059-3, 2018.

Lueck, R. G. and Picklo, J. J.: Thermal inertia of conductivity cells: Observations with a Sea-Bird cell, J. Atmos. Ocean. Technol., 7, 756-768, https://doi.org/10.1175/1520-0426(1990)007<0756:TIOCCO>2.0.CO;2, 1990.

Mahadevan, A.: The impact of submesoscale physics on primary productivity of plankton, Annu. Rev. Mar. Sci., 8, 161-184, https://doi.org/10.1146/annurev-marine-010814-015912, 2016.

Mahadevan, A. and Tandon, A.: An analysis of mechanisms for submesoscale vertical motion at ocean fronts, Ocean Model., 14, 241-256, https://doi.org/10.1016/j.ocemod.2006.05.006, 2006.

Marrec, P., Grégori, G., Doglioli, A. M., Dugenne, M., Della Penna, A., Bhairy, N., Cariou, T., Hélias Nunige, S., Lahbib, S., Rougier, G., Wagener, T., and Thyssen, M.: Coupling physics and biogeochemistry thanks to high-resolution observations of the phytoplankton community structure in the northwestern Mediterranean Sea, Biogeosciences, 15, 1579-1606, https://doi.org/10.5194/bg-15-1579-2018, 2018.

Martin, A.: Phytoplankton patchiness: the role of lateral stirring and mixing, Prog. Oceanogr., 57, 125-174, https://doi.org/10.1016/S00796611(03)00085-5, 2003.

McDougall, T., Jackett, D., Millero, F., Pawlowicz, R., and Barker, P.: A global algorithm for estimating Absolute Salinity., Ocean Sci., 8, 1123-1134, https://doi.org/10.5194/os-8-1123-2012, 2012.

McDougall, T. J. and Barker, P. M.: Getting started with TEOS-10 and the Gibbs Seawater (GSW) Oceanographic Toolbox, SCOR/IAPSO WG, 127, 1-28, 2011. 
https://doi.org/10.5194/bg-2021-38

Preprint. Discussion started: 2 March 2021

(c) Author(s) 2021. CC BY 4.0 License.

(c) (i)

McWilliams, J. C.: Submesoscale currents in the ocean, P. Roy. Soc. A-Math. Phy., 472, 20160 117, https://doi.org/10.1098/rspa.2016.0117, 2016.

Mena, C., Reglero, P., Ferriol, P., Torres, A. P., Aparicio-González, A., Balbín, R., Santiago, R., Moyà, G., Alemany, F., and Agawin, N. S.: Prokaryotic picoplankton spatial distribution during summer in a haline front in the Balearic Sea, Western Mediterranean, Hydrobiologia, 779, 243-257, https://doi.org/10.1007/s10750-016-2825-4, 2016.

540 Mena, C., Reglero, P., Hidalgo, M., Sintes, E., Santiago, R., Martín, M., Moyà, G., and Balbín, R.: Phytoplankton community structure is driven by stratification in the oligotrophic Mediterranean Sea, Front. Microbiol., 10, 1698, https://doi.org/10.3389/fmicb.2019.01698, 2019.

Mensah, V., Le Menn, M., and Morel, Y.: Thermal mass correction for the evaluation of salinity, J. Atmos. Ocean. Technol., 26, 665-672, https://doi.org/10.1175/2008JTECHO612.1, 2009.

Millot, C.: Circulation in the western Mediterranean Sea, J. Marine Syst., 20, 423-442, https://doi.org/10.1016/S0924-7963(98)00078-5, 1999.

Millot, C., Candela, J., Fuda, J.-L., and Tber, Y.: Large warming and salinification of the Mediterranean outflow due to changes in its composition, Deep-Sea Res. Pt. I, 53, 656-666, https://doi.org/10.1016/j.dsr.2005.12.017, 2006.

Morison, J., Andersen, R., Larson, N., D’Asaro, E., and Boyd, T.: The correction for thermal-lag effects in Sea-Bird CTD data, J. Atmos. Ocean. Technol., 11, 1151-1164, https://doi.org/10.1175/1520-0426(1994)011<1151:TCFTLE>2.0.CO;2, 1994.

Morrow, R., Fu, L.-L., Ardhuin, F., Benkiran, M., Chapron, B., Cosme, E., d'Ovidio, F., Farrar, J. T., Gille, S. T., Lapeyre, G., et al.: Global observations of fine-scale ocean surface topography with the Surface Water and Ocean Topography (SWOT) Mission, Front. Mar. Sci., 6, 232, https://doi.org/10.3389/fmars.2019.00232, 2019.

Moutin, T. and Bonnet, S.: OUTPACE cruise, RV L'Atalante., https://doi.org/10.17600/15000900, 2015.

555 Pascual, A., Ruiz, S., Olita, A., Troupin, C., Claret, M., Casas, B., Mourre, B., Poulain, P.-M., Tovar-Sanchez, A., Capet, A., et al.: A multiplatform experiment to unravel meso-and submesoscale processes in an intense front (AlborEx), Front. Mar. Sci., 4, 39, https://doi.org/10.3389/fmars.2017.00039, 2017.

Petrenko, A. A., Doglioli, A. M., Nencioli, F., Kersalé, M., Hu, Z., and d'Ovidio, F.: A review of the LATEX project: mesoscale to submesoscale processes in a coastal environment, Ocean Dynam., 67, 513-533, https://doi.org/10.1007/s10236-017-1040-9, 2017.

Pidcock, R. E., Martin, A. P., Painter, S. C., Allen, J. T., Srokosz, M. A., Forryan, A., Stinchcombe, M., and Smeed, D. A.: Quantifying mesoscale-driven nitrate supply: A case study, Global Biogeochem. Cy., 30, 1206-1223, https://doi.org/10.1002/2016GB005383, 2016.

Ptacnik, R., Solimini, A. G., Andersen, T., Tamminen, T., Brettum, P., Lepistö, L., Willén, E., and Rekolainen, S.: Diversity predicts stability and resource use efficiency in natural phytoplankton communities, Proc. Nat. Acad. Sci. USA, 105, 5134-5138, https://doi.org/10.1073/pnas.0708328105, 2008.

Ribalet, F., Marchetti, A., Hubbard, K. A., Brown, K., Durkin, C. A., Morales, R., Robert, M., Swalwell, J. E., Tortell, P. D., and Armbrust, E. V.: Unveiling a phytoplankton hotspot at a narrow boundary between coastal and offshore waters, Proc. Nat. Acad. Sci. USA, 107, 16 571-16576, https://doi.org/10.1073/pnas.1005638107, 2010.

Rousselet, L., Doglioli, A., de Verneil, A., Pietri, A., Della Penna, A., Berline, L., Marrec, P., Grégori, G., Thyssen, M., Carlotti, F., et al.: Vertical motions and their effects on a biogeochemical tracer in a cyclonic structure finely observed in the Ligurian Sea, J. Geophys. Res.-Oceans, 124, 3561-3574, https://doi.org/10.1029/2018JC014392, 2019.

Rudnick, D. L.: Intensive surveys of the Azores Front: 2. Inferring the geostrophic and vertical velocity fields, J. Geophys. Res.-Oceans, 101, 16 291-16303, https://doi.org/10.1029/96JC01144, 1996. 
https://doi.org/10.5194/bg-2021-38

Preprint. Discussion started: 2 March 2021

(C) Author(s) 2021. CC BY 4.0 License.

(c) (i)

Ruiz, S., Claret, M., Pascual, A., Olita, A., Troupin, C., Capet, A., Tovar-Sánchez, A., Allen, J., Poulain, P.-M., Tintoré, J., et al.: Effects of oceanic mesoscale and submesoscale frontal processes on the vertical transport of phytoplankton, J. Geophys. Res.-Oceans, 124, 59996014, https://doi.org/10.1029/2019JC015034, 2019.

Shcherbina, A. Y., Sundermeyer, M. A., Kunze, E., D’Asaro, E., Badin, G., Birch, D., Brunner-Suzuki, A.-M. E., Callies, J., Kuebel Cervantes, B. T., Claret, M., et al.: The LatMix summer campaign: Submesoscale stirring in the upper ocean, Bull. Amer. Meteorol. Soc., 96, 1257-1279, https://doi.org/10.1175/BAMS-D-14-00015.1, 2015.

Soccodato, A., d'Ovidio, F., Lévy, M., Jahn, O., Follows, M. J., and De Monte, S.: Estimating planktonic diversity through spatial dominance patterns in a model ocean, Mar. Genom., 29, 9-17, https://doi.org/10.1016/j.margen.2016.04.015, 2016.

Strass, V. H.: Chlorophyll patchiness caused by mesoscale upwelling at fronts, Deep-Sea Res., 39, 75-96, https://doi.org/10.1016/01980149(92)90021-K, 1992.

Tang, W., Cerdán-García, E., Berthelot, H., Polyviou, D., Wang, S., Baylay, A., Whitby, H., Planquette, H., Mowlem, M., Robidart, J., et al.: New insights into the distributions of nitrogen fixation and diazotrophs revealed by high-resolution sensing and sampling methods, ISME J., 14, 2514-2526, https://doi.org/10.1038/s41396-020-0703-6, 2020.

Thyssen, M., Garcia, N., and Denis, M.: Sub meso scale phytoplankton distribution in the North East Atlantic surface waters determined with an automated flow cytometer, Biogeosciences, 6, 569-583, https://doi.org/10.5194/bg-6-569-2009, 2009.

Thyssen, M., Alvain, S., Lefèbvre, A., Dessailly, D., Rijkeboer, M., Guiselin, N., Creach, V., and Artigas, L.-F.: High-resolution analysis of a North Sea phytoplankton community structure based on in situ flow cytometry observations and potential implication for remote sensing, Biogeosciences, 12, 4051-4066, https://doi.org/10.5194/bg-12-4051-2015, 2015.

Tintoré, J., Gomis, D., Alonso, S., and Parrilla, G.: Mesoscale dynamics and vertical motion in the Alboran Sea, J. Phys. Oceanogr., 21, 811-823, https://doi.org/10.1175/1520-0485(1991)021<0811:MDAVMI>2.0.CO;2, 1991.

Troupin, C., Beltran, J. P., Heslop, E., Torner, M., Garau, B., Allen, J., Ruiz, S., and Tintoré, J.: A toolbox for glider data processing and management, Methods in Oceanography, 13, 13-23, https://doi.org/10.1016/j.mio.2016.01.001, 2015.

595 Watson, A. J., Robinson, C., Robinson, J., Williams, P. 1. B., and Fasham, M.: Spatial variability in the sink for atmospheric carbon dioxide in the North Atlantic, Nature, 350, 50-53, https://doi.org/10.1038/350050a0, 1991.

Yoder, J. A., McClain, C. R., Blanton, J. O., and Oeymay, L.-Y.: Spatial scales in CZCS-chlorophyll imagery of the southeastern US continental shelf 1, Limnol. Oceanogr., 32, 929-941, https://doi.org/10.4319/lo.1987.32.4.0929, 1987.

Yoder, J. A., Ackleson, S. G., Barber, R. T., Flament, P., and Balch, W. M.: A line in the sea, Nature, 371, 689-692, https://doi.org/10.1038/371689a0, 1994. 
https://doi.org/10.5194/bg-2021-38

Preprint. Discussion started: 2 March 2021

(c) Author(s) 2021. CC BY 4.0 License.

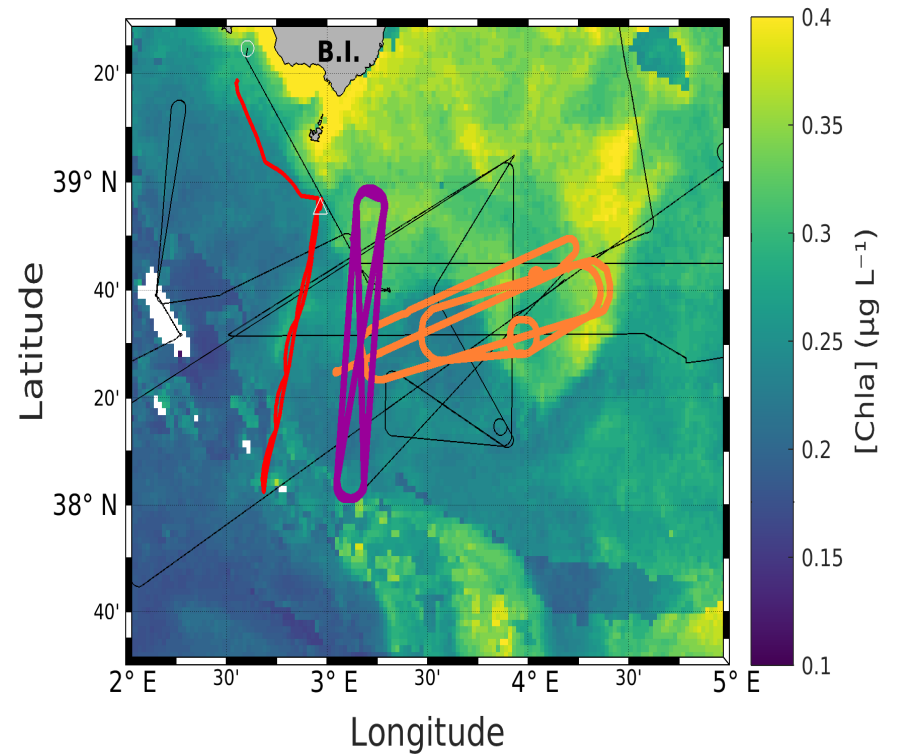

Figure 1. Route of the RV Beautemps-Beaupré during PROTEVSMED-SWOT (black line) superimposed on map of satellite-derived [Chla] provided by CLS for 3 May 2018. The orange and purple lines delimit the two areas called "hippodromes": West-East (orange) and NorthSouth (purple). The red line represents the route of the SeaExplorer glider. 
https://doi.org/10.5194/bg-2021-38

Preprint. Discussion started: 2 March 2021

(c) Author(s) 2021. CC BY 4.0 License.

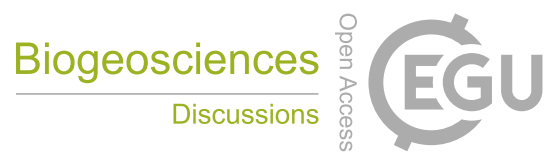

(a)

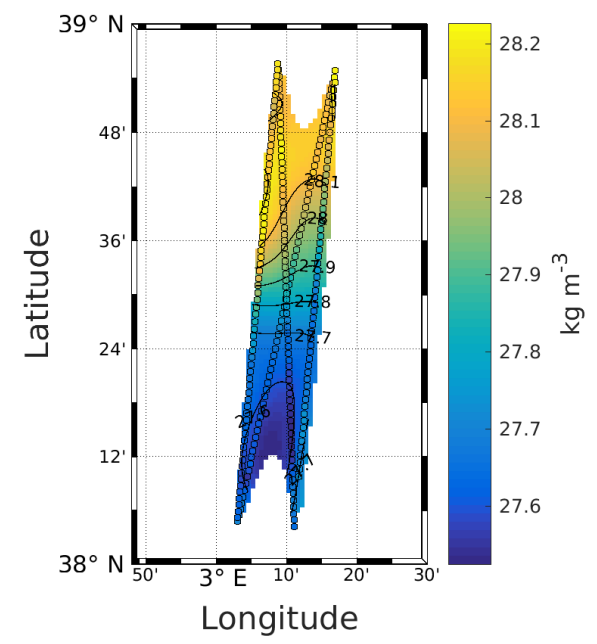

(b)

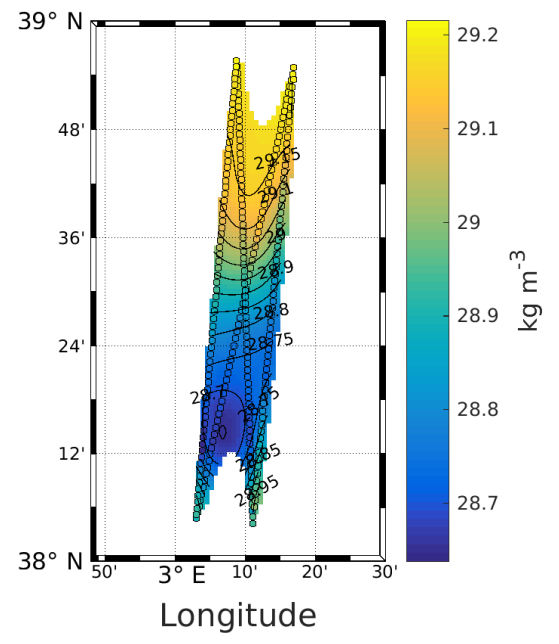

Figure 2. Objective mapping of potential density anomaly $\sigma$ at 25 (a) and $85 \mathrm{~m}$ (b). The circles represent $\sigma$ as measured by the Seasoar, along the transects used for the interpolation. Black lines represent $\sigma$ contours. The data have been selected where the error on the objective mapping of $\sigma$ is $\leq 0.0025$. 
https://doi.org/10.5194/bg-2021-38

Preprint. Discussion started: 2 March 2021

(c) Author(s) 2021. CC BY 4.0 License.

(a)

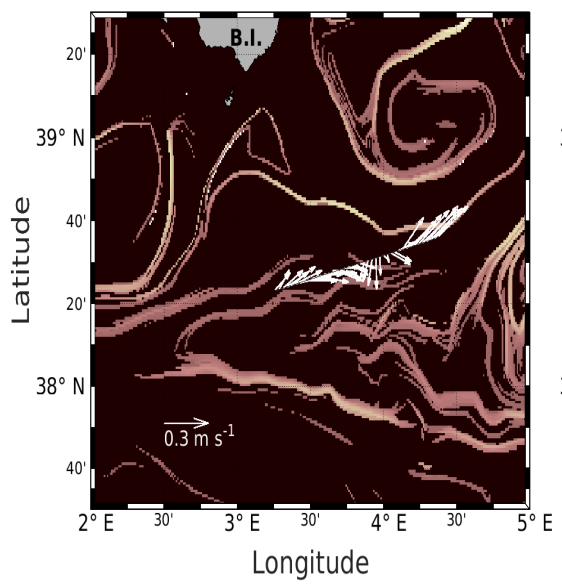

(b)

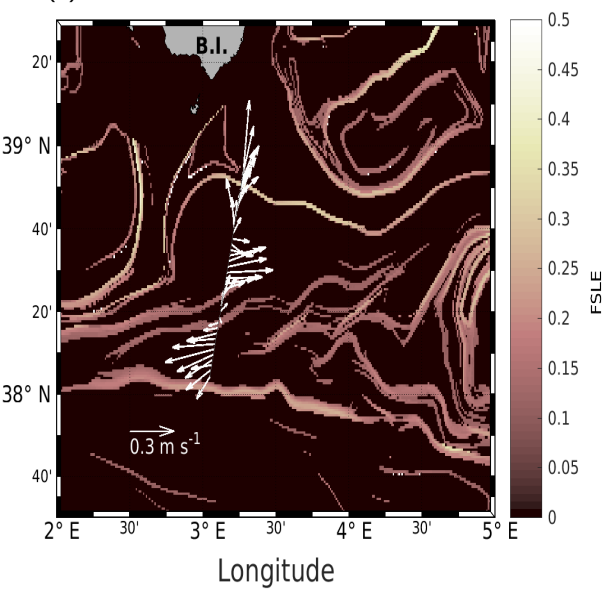

Figure 3. Horizontal velocities measured by VMADCP at $25 \mathrm{~m}$, along the WE (a) and NS (b) transects, superimposed to the FSLE field for the corresponding date (i.e. 9 May 2018 and 11 May 2018, respectively). Unit for FSLE is day ${ }^{-1}$. 
https://doi.org/10.5194/bg-2021-38

Preprint. Discussion started: 2 March 2021

(c) Author(s) 2021. CC BY 4.0 License.

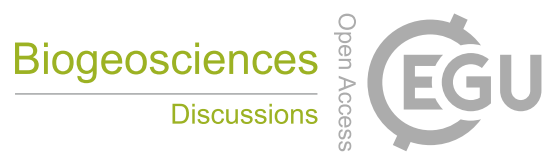

(a)

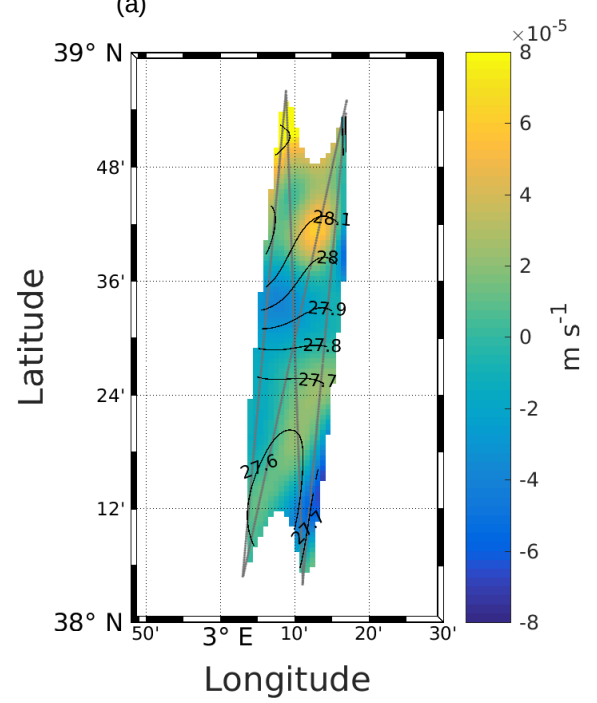

(b)

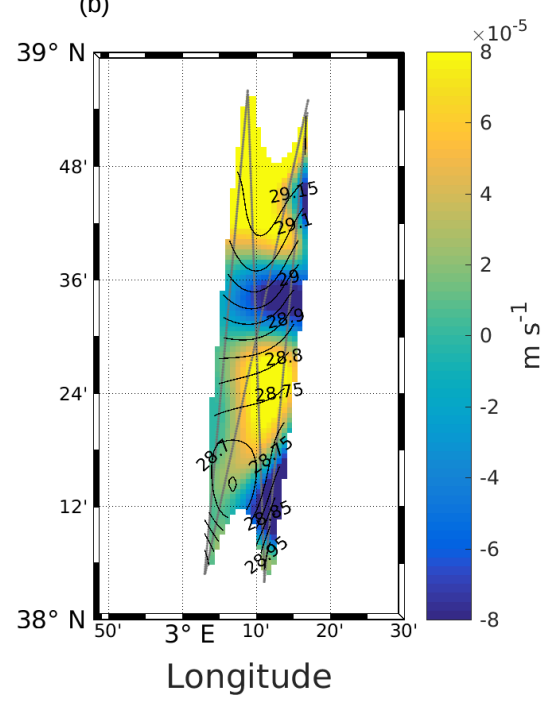

Figure 4. Maps of vertical velocities at (a) $25 \mathrm{~m}$ and (b) $85 \mathrm{~m}$. Black lines represent the $\sigma$ contours. The data have been selected where the error on the objective mapping of $\sigma$ is $\leq 0.0025$. 
https://doi.org/10.5194/bg-2021-38

Preprint. Discussion started: 2 March 2021

(c) Author(s) 2021. CC BY 4.0 License.

(c) (i)

(a)

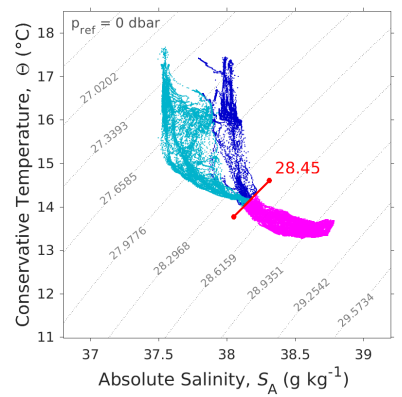

(c)

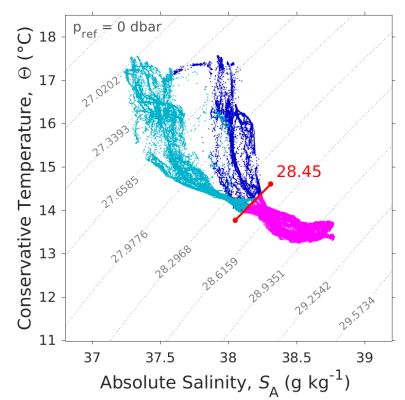

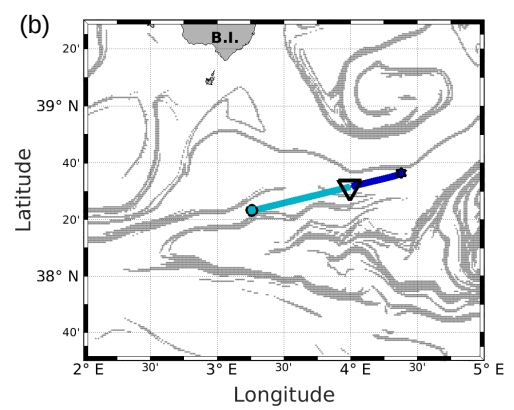

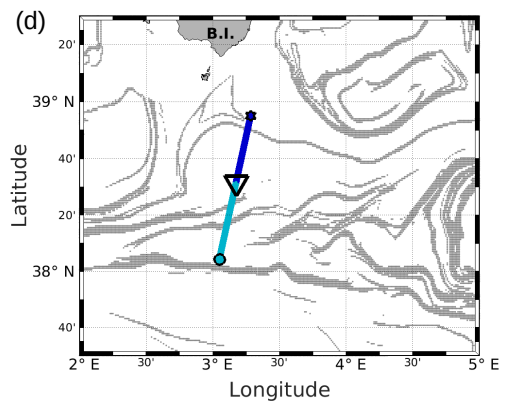

Figure 5. $\Theta-S_{A}$ diagrams of data collected along the WE (a) and the NS (c) transects. The "younger" AW is represented in light blue whereas the "older" AW is represented in dark blue. Intermediate water is also represented in pink. The isopycnal $28.45 \mathrm{~kg} \mathrm{~m}{ }^{-3}$, separating surface waters from the deeper ones, is pointed out in red. Triangles in panels (b) and (d) indicate the geographical position of the separation between the two types of AW along the corresponding transect. 
https://doi.org/10.5194/bg-2021-38

Preprint. Discussion started: 2 March 2021

(c) Author(s) 2021. CC BY 4.0 License.

(c) (1)

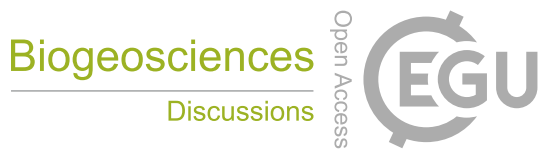

(a)

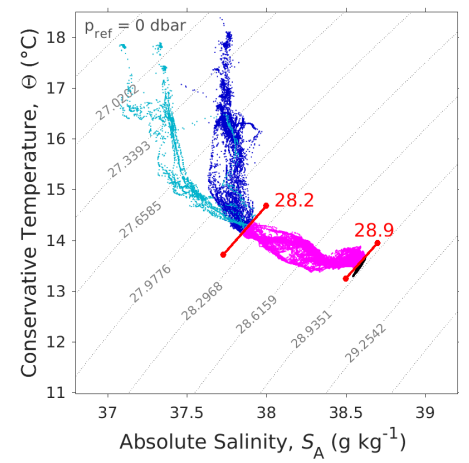

(b)

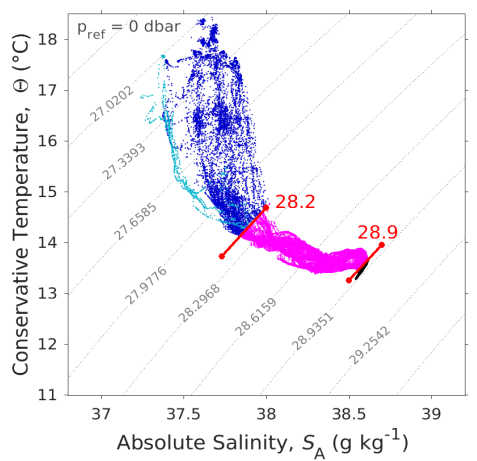

Figure 6. $\Theta-S_{A}$ diagrams measured by the SeaExplorer glider along the outward route (a): 6 May 2018 00:00-9 May 2018 21:00 UTC, and the return route (b): 10 May 2018 00:00-13 May 2018 21:00 UTC. As in Figure 5, the "younger" AW is represented in light blue whereas the "older" AW is represented in dark blue. Intermediate water and deeper water are represented in pink and black, respectively. The isopycnals 28.2 and $28.9 \mathrm{~kg} \mathrm{~m}^{-3}$, separating surface waters from the deeper ones, are also shown. 
https://doi.org/10.5194/bg-2021-38

Preprint. Discussion started: 2 March 2021

(c) Author(s) 2021. CC BY 4.0 License.

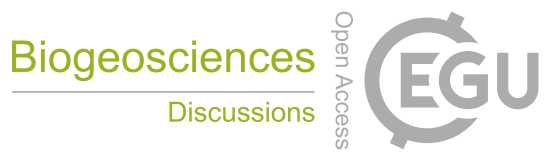

(c) (i)
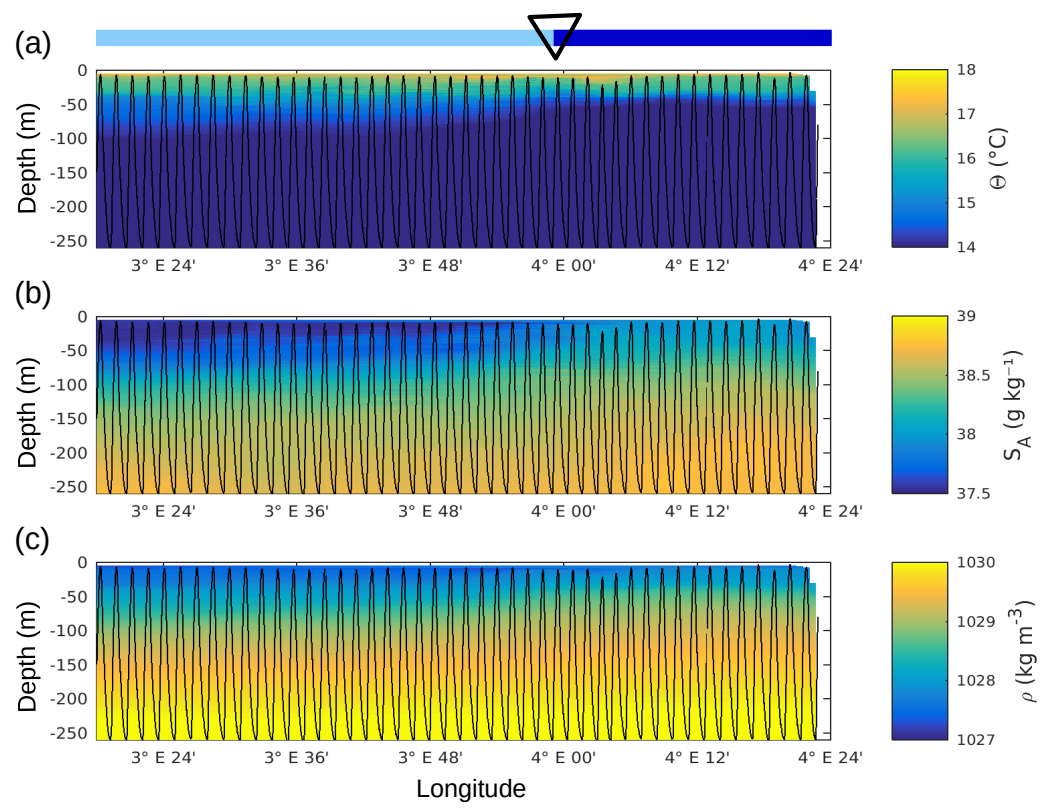

Figure 7. Vertical sections of conservative temperature $\Theta$ (a), absolute salinity $S_{A}$ (b), and density $\rho$ (c), sampled by the Seasoar along the WE transect. The Seasoar trajectory is represented by the black lines. Triangle indicates the localisation of the front area between the two types of AW represented in light and dark blue (see Fig. 5b). 
https://doi.org/10.5194/bg-2021-38

Preprint. Discussion started: 2 March 2021

(c) Author(s) 2021. CC BY 4.0 License.
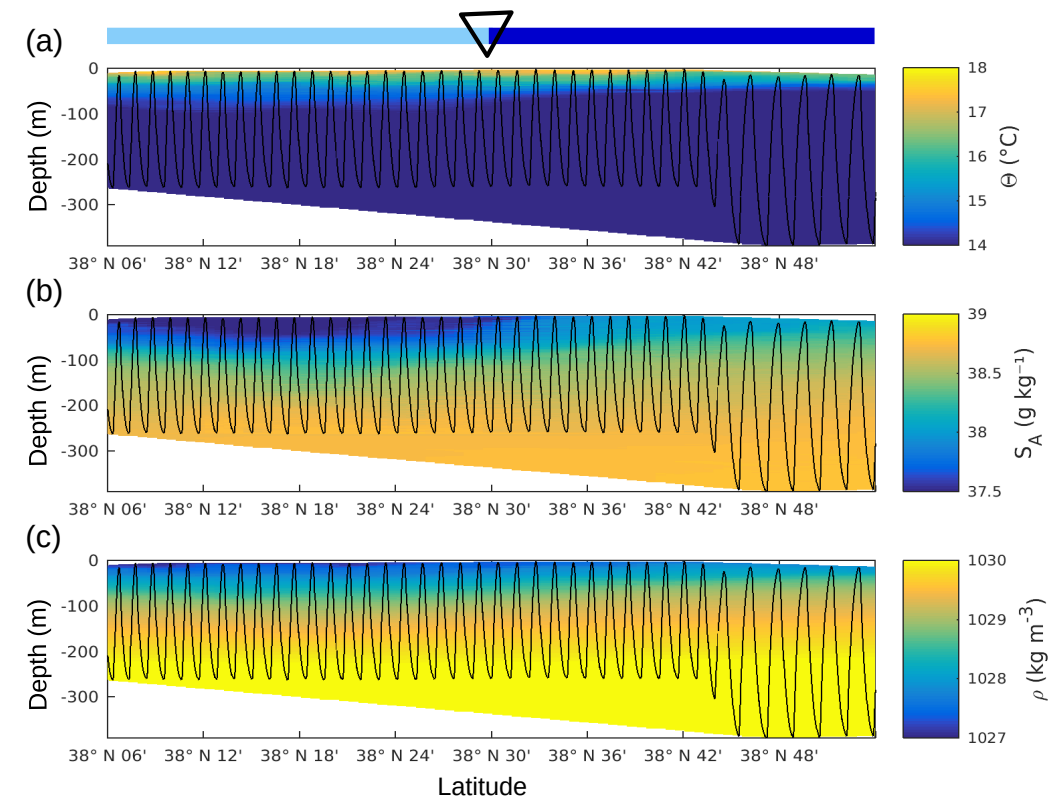

Figure 8. Vertical sections of conservative temperature $\Theta$ (a), absolute salinity $S_{A}$ (b), and density $\rho$ (c), sampled by the Seasoar along the NS transect. The Seasoar trajectory is represented by the black lines. Triangle indicates the localisation of the front area between the two types of AW represented in light and dark blue (see Fig. 5c). 
https://doi.org/10.5194/bg-2021-38

Preprint. Discussion started: 2 March 2021

(c) Author(s) 2021. CC BY 4.0 License.

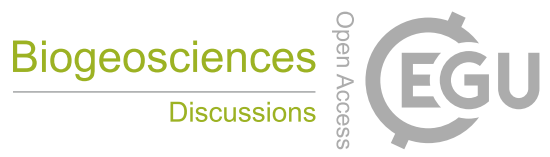

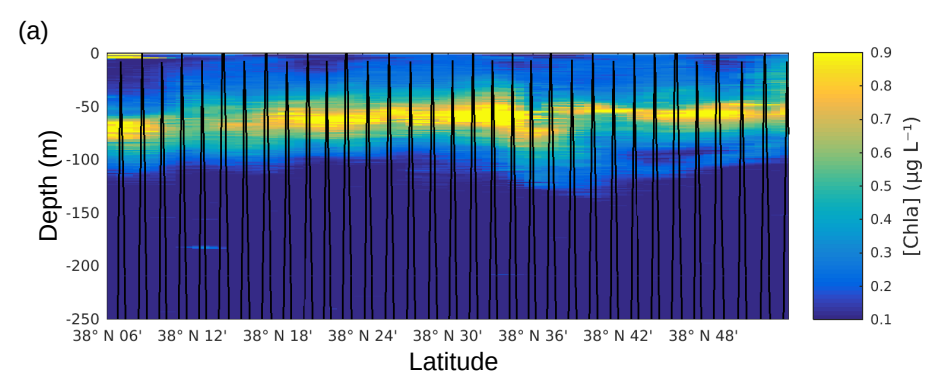

(b)

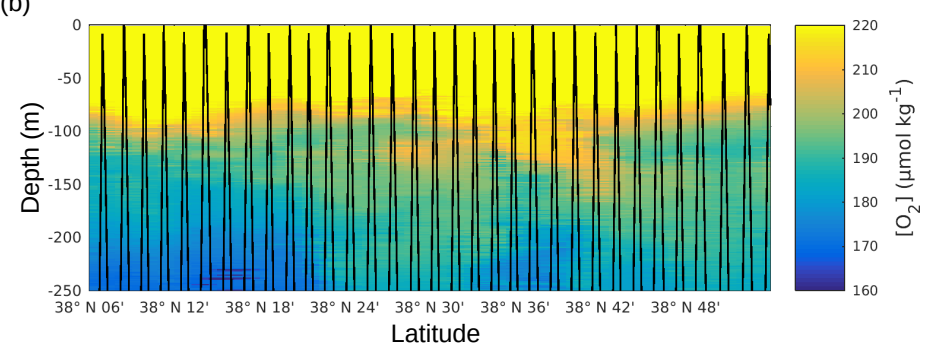

Figure 9. Vertical profiles of [Chla] (a) and dissolved oxygen concentration (b), measured by the SeaExplorer glider, along the outward route: 6 May 2018 00:00-9 May 2018 21:00 UTC. The SeaExplorer glider trajectory is represented by the black lines. The data have been selected between the surface and $250 \mathrm{~m}$ for a better visualization of the surface layer. 
https://doi.org/10.5194/bg-2021-38

Preprint. Discussion started: 2 March 2021

(c) Author(s) 2021. CC BY 4.0 License.

(a)

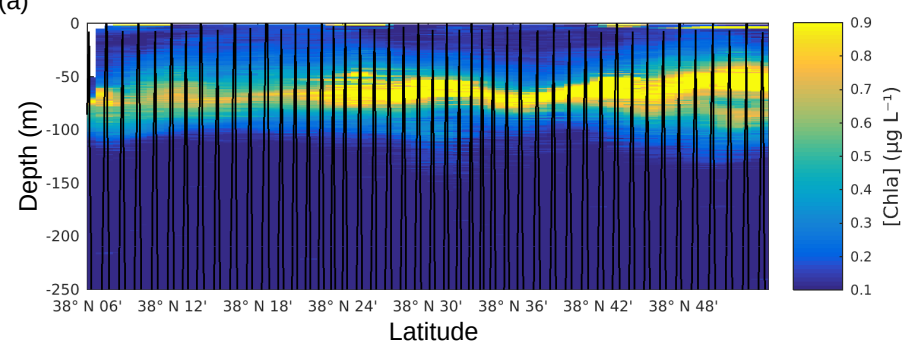

(b)

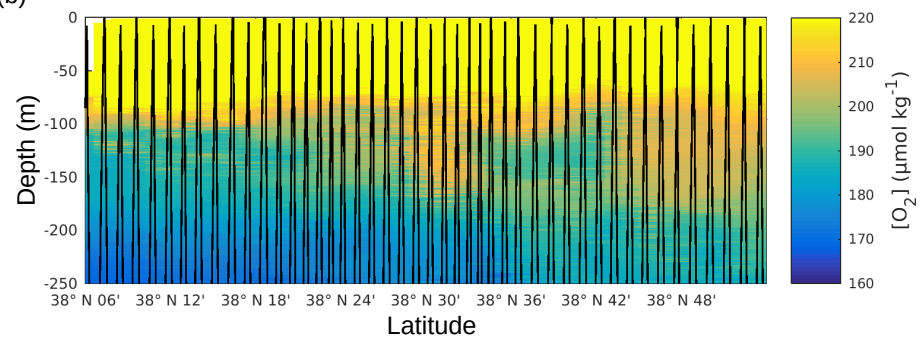

Figure 10. As in Fig. 9, but for return route: 10 May 2018 00:00-13 May 2018 21:00 UTC. 
https://doi.org/10.5194/bg-2021-38

Preprint. Discussion started: 2 March 2021

(c) Author(s) 2021. CC BY 4.0 License.

(c) (i)

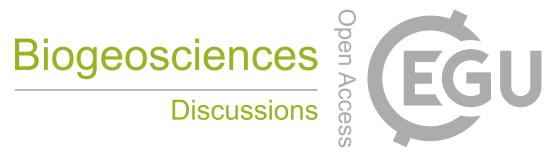

(a)

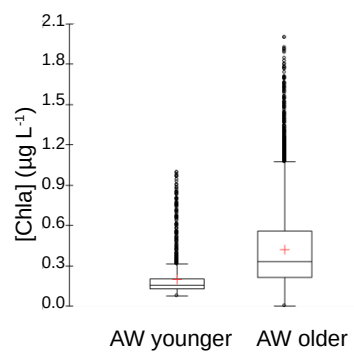

(b)

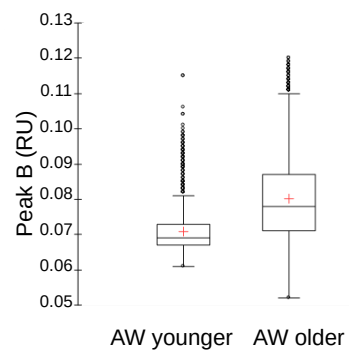

(c)

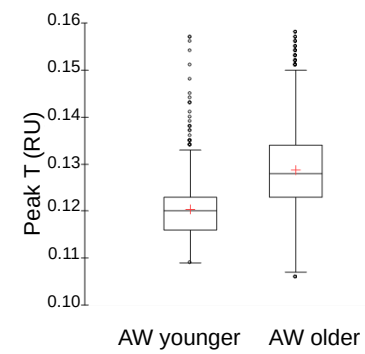

Figure 11. Box-and-whisker plots for the comparison of (a) [Chla] (in microgram per litre), (b) fluorescence intensities of tyrosine-like fluorophore (Peak B in RU) and (c) fluorescence intensities of tryptophan-like fluorophore (Peak T in RU) between "younger" and "older" Atlantic Waters (AW). The bottom and top of the box are the 25th and 75th percentiles, respectively, whereas the central line is the 50th percentile (the median), and the cross is the mean. The ends of the error bars correspond to the 10th percentile (bottom) and to 90th percentile (top). All the SeaExplorer glider transects are considered here (all data acquired from 6 to 15 May 2018). "Younger AW" correspond to samples showing a salinity between 37.20 and 37.84 , and a temperature between 14.5 and $17.4{ }^{\circ} \mathrm{C}(\mathrm{n}=1657)$. "Older AW" correspond to samples displaying a salinity between 37.82 and 38.14, and a temperature between 14.0 and $18.3{ }^{\circ} \mathrm{C}(\mathrm{n}=11760)$. Mean values of Chla, Peak $\mathrm{B}$ and Peak T of "older AW" are significantly higher than those of "younger AW" (t test, p inf 0.0001). 
https://doi.org/10.5194/bg-2021-38

Preprint. Discussion started: 2 March 2021

(c) Author(s) 2021. CC BY 4.0 License.

(c) (i)
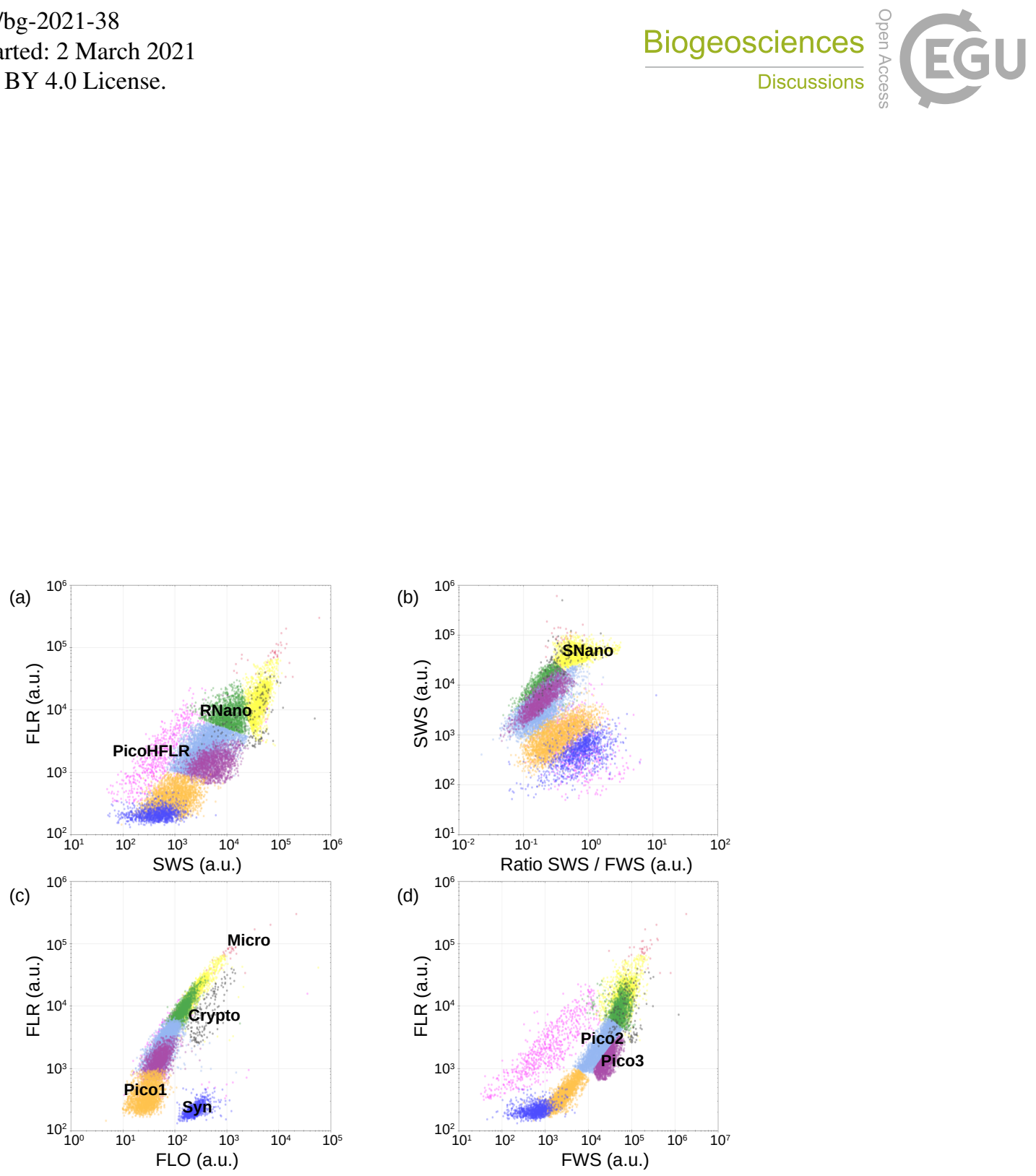

Figure 12. Cytograms obtained with the CytoSense automated flow cytometer. Synechococcus are in dark blue (Syn), the picophytoplankton with lowest FLO in orange (Pico1), the picophytoplankton with intermediate FWS in light blue (Pico2), the picophytoplankton with highest FWS in violet (Pico3), the picophytoplankton with a high red fluorescence in pink (PicoHFLR), the nanophytoplankton with high SWS/FWS ratio in yellow (SNano) and higher SWS intensities than the other nanophytoplankton (RNano) in green, the Cryptophytes in grey (Crypto) and the microphytoplankton in red (Micro). The flow cytometry units for both fluorescence and light scatter are arbitrary (a.u). 
https://doi.org/10.5194/bg-2021-38

Preprint. Discussion started: 2 March 2021

(c) Author(s) 2021. CC BY 4.0 License.

\section{(c) (1)}

(a)

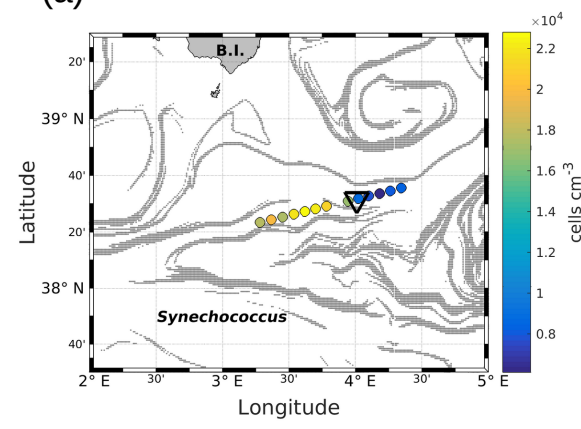

(c)

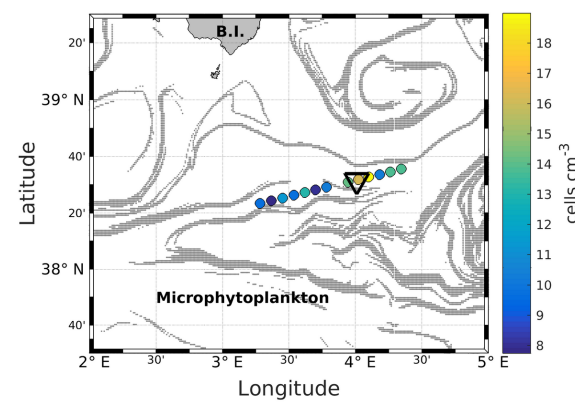

(b)

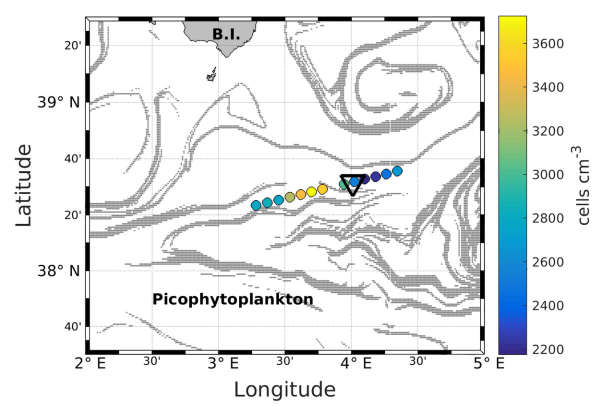

(d)

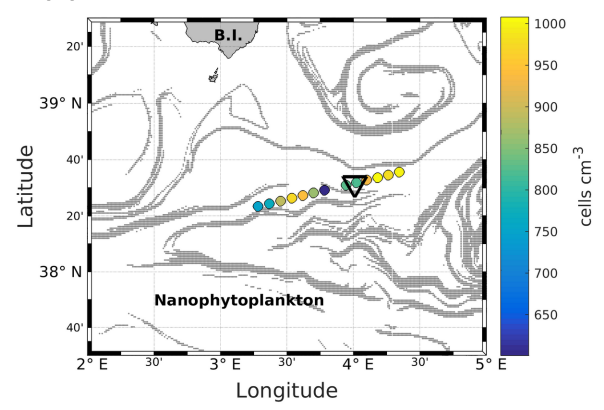

(e)

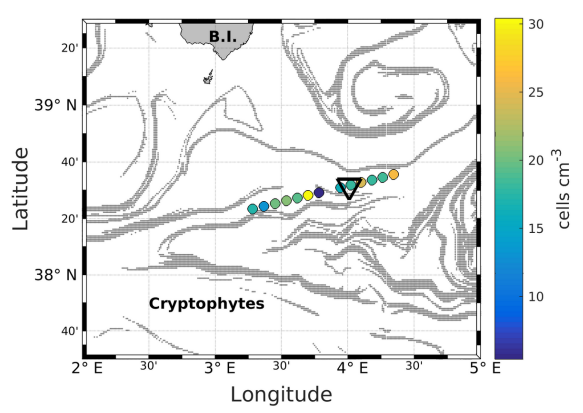

Figure 13. Abundances (in cells per cubic centimeter) of the phytoplankton groups along the WE transect, superimposed with the FSLE field. Triangles indicate the front area. (a) Synechococcus , (b) Picophytoplankton, (c) Microphytoplankton, (d) Nanophytoplankton, (e) Cryptophytes. 
https://doi.org/10.5194/bg-2021-38

Preprint. Discussion started: 2 March 2021

(c) Author(s) 2021. CC BY 4.0 License.

\section{(c) (1)}

(a)

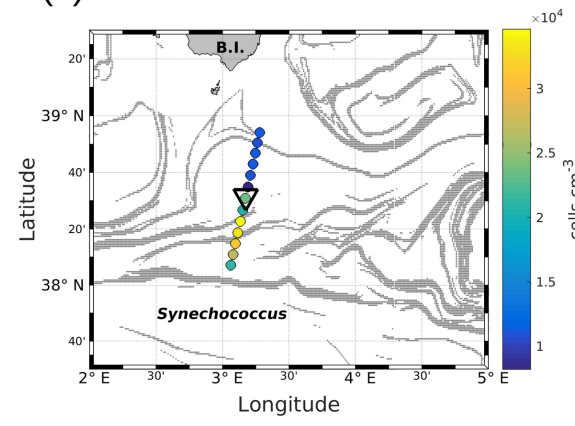

(c)

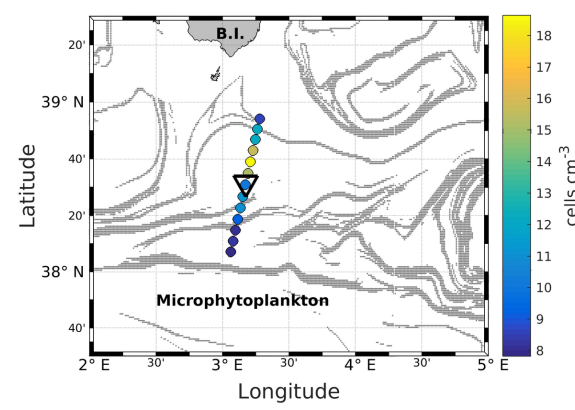

(b)

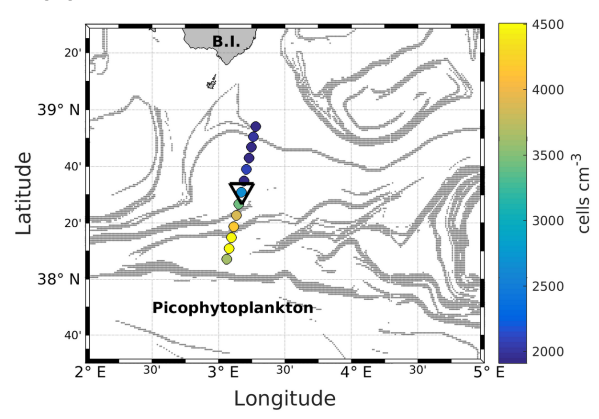

(d)

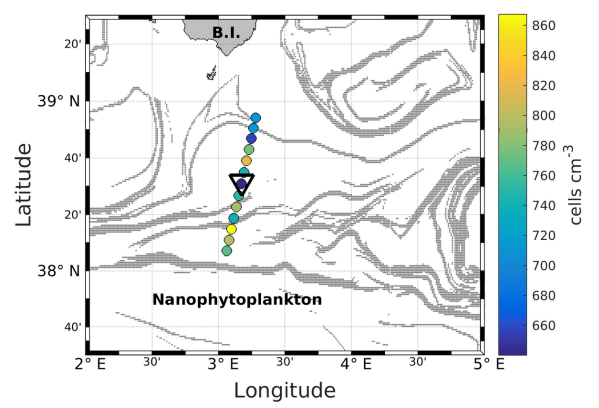

(e)

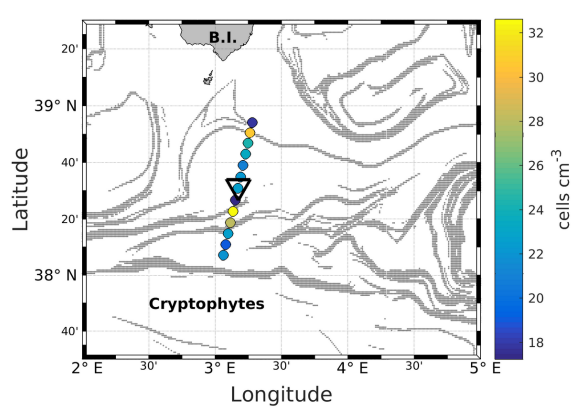

Figure 14. As in Fig. 13, but for NS transect. 
https://doi.org/10.5194/bg-2021-38

Preprint. Discussion started: 2 March 2021

(c) Author(s) 2021. CC BY 4.0 License.

(c) (i)

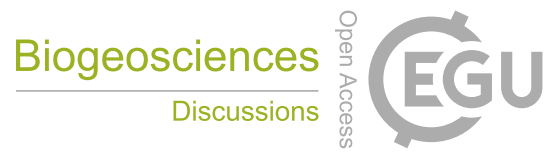

(a)

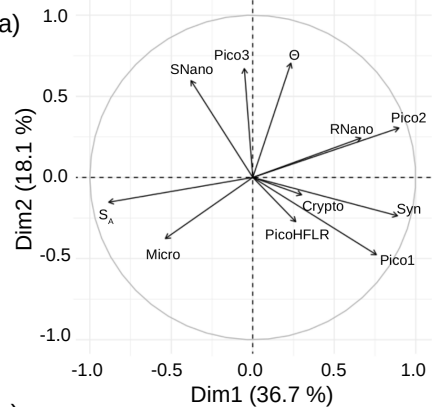

(c)

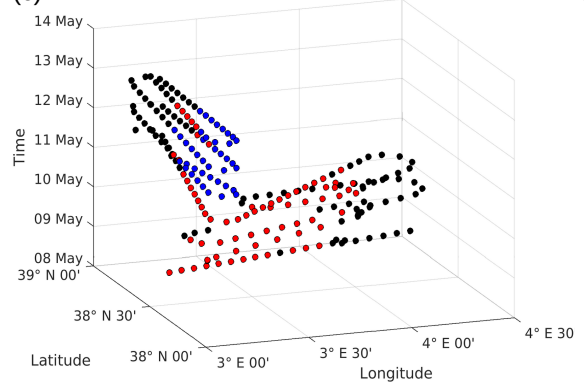

(b)

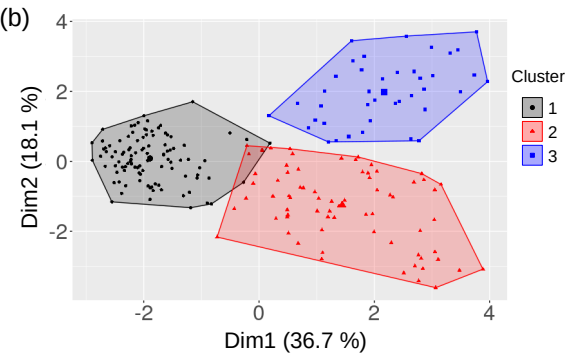

(d)

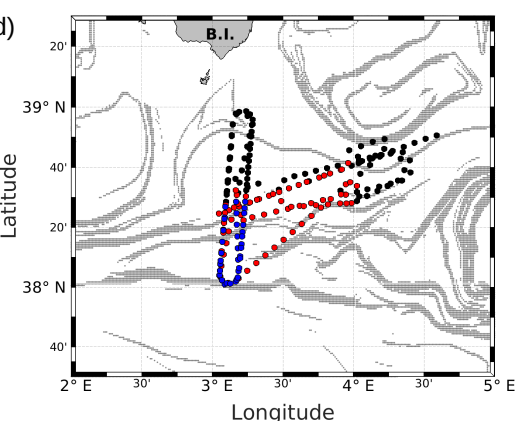

Figure 15. (a) Principal component analysis in the first factorial plane. (b) Representation in two dimensions of the three clusters obtained with the K-medoid algorithm. (c) Spatio-temporal representation of the three clusters obtained with the K-medoid algorithm. (d) Geographical representation of these clusters, superimposed to the FSLE field of the 11 May 2018. 
https://doi.org/10.5194/bg-2021-38

Preprint. Discussion started: 2 March 2021

(c) Author(s) 2021. CC BY 4.0 License.

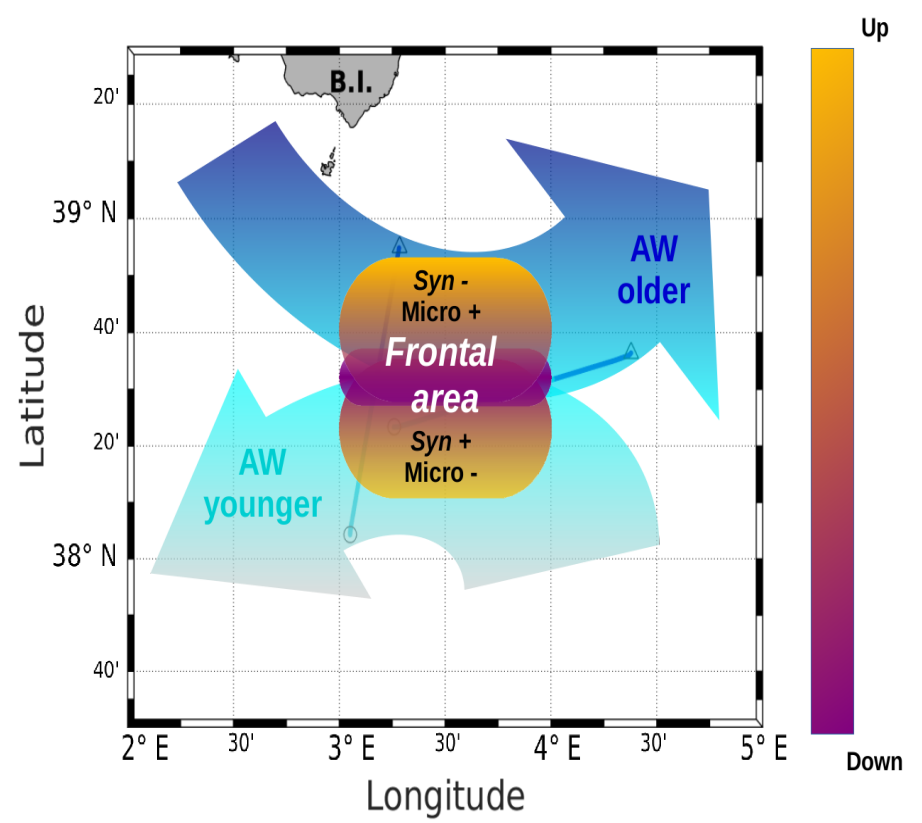

Figure 16. A schematic view of the of PROTEVSMED-SWOT results in the surface layer. A narrow frontal area, characterized by the change in direction of the horizontal current and by opposite vertical movements, corresponds to a rapid shift in hydrological properties and biological content of the two water masses separated by the front. For sake of simplicity only two groups of phytoplankton, Synechococcus (Syn) and Microphytoplankton (Micro), are indicated, but their contrasted abundances are also representative of the ones of other phytoplankton groups. 
https://doi.org/10.5194/bg-2021-38

Preprint. Discussion started: 2 March 2021

(c) Author(s) 2021. CC BY 4.0 License.

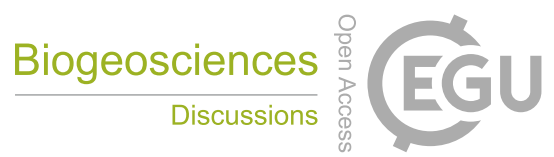

(c) (1)

Table 1. Results of the iterative algorithm to determine the best separation between the two types of AW along the Seasoar transects of the WE and NS hippodromes. The lines in bold correspond to the WE and the NS transects represented in Fig. 5. Only one transect is available for WE hippodrome due to technical problems with the towed fish.

\begin{tabular}{ccccc}
\hline Date of transects (Time UTC) & $\left(\overline{S_{A 1}}, \overline{\Theta_{1}}\right)$ & $\left(\overline{S_{A 2}}, \overline{\Theta_{2}}\right)$ & Max of $\left|\overline{S_{A 1}}-\overline{S_{A 2}}\right|\left(\mathrm{g} \mathrm{kg}^{-1}\right)$ & Lon / Lat of best separation \\
\hline 9 May 16:50-9 May 23:45 & $(\mathbf{3 7 . 7 1 , 1 5 . 6 2})$ & $\mathbf{( 3 8 . 0 2}, \mathbf{1 5 . 9 3})$ & $\mathbf{0 . 3 1}$ & $\mathbf{4}^{\circ} \mathbf{E ~ 0 6}$ \\
11 May 02:00-11 May 08:40 & $\mathbf{( 3 7 . 6 3 , 1 5 . 6 8 )}$ & $\mathbf{( 3 8 . 0 3 , 1 5 . 9 1 )}$ & $\mathbf{0 . 4 0}$ & $\mathbf{3 8}^{\circ} \mathbf{~ N ~ 3 2}$ \\
11 May 10:00-11 May 16:45 & $(37.59,15.95)$ & $(38.03,15.69)$ & 0.44 & $38^{\circ} \mathrm{N} 30^{\prime}$ \\
11 May 17:55-12 May 00:50 & $(37.63,16.02)$ & $(38.07,15.61)$ & 0.44 & $38^{\circ} \mathrm{N} 34^{\prime}$ \\
12 May 01:50-12 May 08:20 & $(37.63,15.82)$ & $(38.01,16.15)$ & 0.38 & $38^{\circ} \mathrm{N} 31^{\prime}$ \\
12 May 09:30-12 May 16:40 & $(37.63,15.54)$ & $(38.03,16.09)$ & 0.40 & $38^{\circ} \mathrm{N} 29^{\prime}$ \\
12 May 17:30-13 May 00:20 & $(37.75,15.43)$ & $(38.05,16.30)$ & 0.30 & $38^{\circ} \mathrm{N} 34^{\prime}$ \\
\hline
\end{tabular}


https://doi.org/10.5194/bg-2021-38

Preprint. Discussion started: 2 March 2021

(C) Author(s) 2021. CC BY 4.0 License.

(c) (i)

Table 2. Size and abundances of phytoplankton groups. The abundances of nanophytoplankton and picophytoplankton represent the sum of the abundances of the various groups of eukaryotic nanophytoplankton (RNano and SNano) and eukaryotic picophytoplankton (Pico1, Pico2, Pico3 and PicoHFLR) identified on Fig. 12.

\begin{tabular}{|c|c|c|}
\hline Groups & Size $(\mu \mathrm{m})$ & Abundances $\left(\right.$ cells $\mathrm{cm}^{-3}$ ) \\
\hline Synechococcus & 1 & $10^{4}$ \\
\hline Picophytoplankton & $0.2-2$ & $10^{3}$ \\
\hline Nanophytoplankton & $2-20$ & $10^{2}-10^{3}$ \\
\hline Microphytoplankton & $20-200$ & 10 \\
\hline Cryptophytes & $10-50$ & 1 \\
\hline
\end{tabular}


https://doi.org/10.5194/bg-2021-38

Preprint. Discussion started: 2 March 2021

(c) Author(s) 2021. CC BY 4.0 License.

Table 3. Description of the three clusters obtained with the K-medoid algorithm and represented on Fig. 15b, c and d. The local average (i.e. the average of each variables in a cluster) have been compared with the global average (i.e. the average of each variables for all the dataset) to highlight the contribution of each variable to a cluster. Note that only the five most discriminating variables, determined with the standard deviation are shown for each cluster. Absolute salinitiy is measured in gram per kilogram, conservative temperature in degree Celsius and the phytoplankton abundances in cells per cubic centimeter. The bold lines represent the variables with the most contribution of each cluster (i.e. with local average $>$ global average).

\begin{tabular}{|c|c|c|c|c|c|}
\hline Clusters & Variables & Local average & Global average & Local standard deviation & Global standard deviation \\
\hline \multirow[t]{5}{*}{1 (Black) } & Salinity $\left(\mathbf{S}_{A}\right)$ & 37.65 & 37.45 & 0.115 & 0.235 \\
\hline & Microphytoplankton (Micro) & 14 & 11 & 5 & 5 \\
\hline & Nanophytoplankton (SNano) & 461 & 417 & 65 & 86 \\
\hline & Temperature $(\Theta)$ & 18.1 & 18.2 & 0.4 & 0.4 \\
\hline & Nanophytoplankton (RNano) & 386 & 454 & 81 & 140 \\
\hline \multirow[t]{5}{*}{2 (Red) } & Phytoplankton (Pico1) & 1148 & 838 & 361 & 343 \\
\hline & Synechococcus (Syn) & 23820 & 16949 & 5049 & 7699 \\
\hline & Phytoplankton (Pico2) & 1955 & 1656 & 355 & 770 \\
\hline & Microphytoplankton (Micro) & 10 & 11 & 4 & 5 \\
\hline & Temperature $(\Theta)$ & 18 & 18.2 & 0.3 & 0.4 \\
\hline \multirow[t]{5}{*}{3 (Blue) } & Phytoplankton (Pico2) & 2761 & 1657 & 467 & 770 \\
\hline & Temperature $(\Theta)$ & 18.7 & 18.2 & 0.3 & 0.4 \\
\hline & Nanophytoplankton (RNano) & 593 & 454 & 186 & 140 \\
\hline & Phytoplankton (Pico3) & 557 & 355 & 280 & 212 \\
\hline & Synechococcus (Syn) & 22151 & 16949 & 3940 & 7693 \\
\hline
\end{tabular}

